\title{
МАТРИМОНИАЛЬНОЕ ПОВЕДЕНИЕ РОССИЯН НА ФОНЕ ДРУГИХ ЕВРОПЕЙЦЕВ
}

\author{
АЛЕНА АРТАМОНОВА, ЕКАТЕРИНА МИТРОФАНОВА
}

\begin{abstract}
Первая задача данной работь - представить обзор, в котором кратко описывается, как современные исследования объясняют изменения в матримониальном поведении во времени и пространстве (гетерогенность между европейскими странами и внутри России). Вторая задача вылелить основные детерминанты выбора первого матримониального союза, действующие на макро-, мезо- и микроуровнях. Третья и основная задача состояла в поиске ответа на вопрос о том, как изменения в матримониальном поведении россиян соотносятся с тенденциями, наблюдаемыми в других европейских странах. Для этого использовались данные второй волны международного обследования «Поколение и Гендер» и панельная часть трех волн российской части того же обследования.
\end{abstract}

Было выявлено, что в России происходят изменения, характерные для унифицирующихся социальных пространств индустриальных и постиндустриальных обществ: увеличение числа партнеров в течение жизни, постепенное снижение доли людей, вступающих в брак, повышение доли условно одиноких, снижение числа вторых браков. На макроуровне межстрановые различия матримониального поведения объясняются исторически сформировавшимся в стране типом брачности, профилем ценностей граждан, режимом семейной политики государства. В России, как и в других странах, на мезоуровне выбор сожительства или брака в качестве первого брачнопартнерского союза детерминирует тип населенного пункта проживания, а на микроуровне возраст вступления в союз, предшествие зачатия вступлению в союз, матримониальный опыт родителей, обстоятельства покидания родительского дома и выхода на рынок труда, уровень образования.

Ключевые слова: первый матримониальный союз, брак, сожительство, жизненный путь, второй демографический переход.

\section{ИЗМЕНЕНИЯ В МАТРИМОНИАЛЬНОМ ПОВЕДЕНИИ: ОБЗОР ИССЛЕДОВАНИЙ И ПОИСК ДЕТЕРМИНАНТ}

C середины прошлого века матримониальное поведение населения многих стран претерпело значительные изменения. Наблюдалось повышение возраста вступления в первый матримониальный союз, увеличение доли незарегистрированных союзов, рост уровня разводимости, увеличение доли людей, никогда не состоящих в браке [Avdeev, Monnier 2000; Klijzing, Corijn 2001; Mills 2004; Puur et al 2012; Захаров, Исупова 2014; Perelli-Harris, Lyons-Amos 2015].

\footnotetext{
АЛЕНА ВяЧЕСЛАвОВНА АРТАМОНОВА (aaaav@iscte-iul.pt), УНИВЕРСИТЕТСКИЙ ИНСТИТУТ ЛИССАБОНА, ПОРТУГАЛИЯ (КООРДИНИРУЮЩИЙ); ГЁТЕБОРГСКИЙ УНИВЕРСИТЕТ, ШВЕЦИЯ; УНИВЕРСИТЕТ СТАВАНГЕРА, НОРВЕГИЯ; УНИВЕРСИТЕТ МАКЕРЕРЕ, УГАНДА.
}

ЕКАТЕРИНА СЕРГЕЕВНА МИТРОФАНОВА (emitrofanova@hse.ru), НАЦИОНАЛЬНЫЙ ИССЛЕДОВАТЕЛЬСКИЙ УНИВЕРСИТЕТ «ВЫСШАЯ ШКОЛА ЭКОНОМИКИ», РОССИЯ.

СТАТЬЯ ПОДГОТОВЛЕНА В ХОДЕ ПРОВЕДЕНИЯ ИССЛЕДОВАНИЯ № 16-О5-ОО11 «РАЗРАБОТКА И АПРОБАЦИЯ МЕТОДИК АНАЛИЗА ДЕМОГРАФИЧЕСКИХ ПОСЛЕДОВАТЕЛЬНОСТЕЙ» В РАМКАХ ПРОГРАММЫ НАУЧНОГО ФОНДА НАЦИОНАЛЬНОГО ИССЛЕДОВАТЕЛЬСКОГО УНИВЕРСИТЕТА ВЫСШАЯ ШКОЛА ЭКОНОМИКИ» (НИУ ВШЭ) В 2016 Г. С ИСПОЛЬЗОВАНИЕМ СРЕДСТВ СУБСИДИИ НА ГОСУДАРСТВЕННУЮ ПОДДЕРЖКУ ВЕДУЩИХ УНИВЕРСИТЕТОВ РОССИЙСКОЙ ФЕДЕРАЦИИ В ЦЕЛЯХ ПОВЫШЕНИЯ ИХ КОНКУРЕНТОСПОСОБНОСТИ СРЕДИ ВЕДУЩИХ МИРОВЫХ НАУЧНО-ОБРАЗОВАТЕЛЬНЫХ ЦЕНТРОВ, ВЫДЕЛЕННОЙ НИУ ВШЭ.

СТАТЬЯ ПОСТУПИЛА В РЕДАКЦИЮ В ДЕКАБРЕ 2017 Г. 
Принятие решения о том, в какой союз вступать - зарегистрированный брак или незарегистрированное сожительство, - становится актуальным для жителей большинства развитых стран: церковное и государственное давление на индивида, стимулирующее заключать именно официальный союз (брак или, ранее, - венчание) перестает формировать единственно возможную линию поведения в матримониальной сфере. Легитимация сожительств сделала их приемлемой формой совместного проживания людей, которая перестала стигматизироваться и осуждаться.

Мы продолжаем исследование вопроса изменений в брачно-партнерском поведении, фокусируясь на странах Европы и, главным образом, - на России. Первая задача данного исследования - представить обзор, в котором кратко иллюстрируется, как современные исследования объясняют изменения в матримониальном поведении во времени и пространстве (гетерогенность между европейскими странами и внутри России). Вторая задача - выделить основные детерминанты выбора первого матримониального союза. Третья и основная задача состояла в поиске ответа на вопрос о том, как изменения в матримониальном поведении россиян соотносятся с тенденциями, наблюдаемыми в других европейских странах. Понимание того, насколько россияне похожи в брачно-партнерском поведении на других европейцев, может помочь в прогнозировании дальнейших изменений, которые уже происходят в странах, более модернизированных в области формировании семьи.

Проанализировав большое число работ, мы выбрали в качестве основной теоретической рамки подход, который предполагает деление факторов матримониального поведения на три группы: макро-, мезо- и микроуровня [Balbo, Billari, Mills 2013]. Такой подход позволяет систематизировать все многообразие этих факторов и представить их в максимально понятном формате. Рассмотрим каждый из обозначенных уровней.

\section{Уровень культурных и социальных институтов (макроуровень)}

Рассмотрим современные исследования изменений в матримониальном поведении в разных странах, а также их возможные детерминанты, функционирующие на макроуровне. Эти детерминанты лягут в основу модели данного исследования, поэтому их детальное рассмотрение видится важным в рамках данной работы.

В соответствии с исследованиями западных и российских демографов, развитые страны можно разделить на несколько групп-кластеров. К первой из них можно отнести страны Восточной и Центральной Европы, где сдвиги в организации жизненного пути на момент исследования были не слишком значительны и преобладала предопределенность сравнительно раннего вступления в брак и рождения первого ребенка. Вторая группа страны Южной Европы и Япония, в которых отмечалось весьма заметное увеличение возраста вступления в первый брак и откладывание рождения детей на фоне низкой распространенности незарегистрированных союзов и внебрачных рождений. К последнему кластеру традиционно относят страны Скандинавии и Западной Европы, где разделились во времени точки начала матримониальной и репродуктивной биографий. К этим странам по своим характеристикам близка Канада, в которой распространены незарегистрированные союзы, рождение и воспитание ребенка вне брака [Демографическая модернизация России 2006: 143-144]. 
В ходе исследования “Траектории формирования семьи в Румынии, Российской Федерации и Франции: навстречу второму демографическому переходу?” [Mills, Lesnard, Potarca 2013] также было выявлено, что изменения в траекториях формирования семьи, заключающиеся в широком распространении сожительств и практике рождения и воспитания детей вне брака, наиболее заметны в странах Западной Европы, которые репрезентировала Франция, в России эти изменения выражены скромнее, но они все же более заметны, чем в странах Восточной Европы, положение в которых было продемонстрировано в исследовании на примере Румынии. Авторы опирались на данные обследования «Поколение и Гендер» и рассматривали последовательности наступления матримониальных и репродуктивных событий в упомянутых странах. Брачно-партнерское поведение во Франции выглядит более разнообразным в сравнении с Россией и Румынией.

Еще дальше в изучении данного вопроса продвинулись демографы, фокусом исследования которых были изменения в практиках формирования матримониального союза в четырнадцати европейских странах и Соединенных Штатах Америки [Perelli-Harris, Lyons-Amos 2015]. Исследователи рассмотрели отрезки жизненного пути в матримониальной сфере женщин в возрасте от 15 до 45 лет из трех когорт (1945-1954, 1955-1964 и 1965-1974 годов рождения). Процедура кластеризации позволила демографам выделить несколько основных путей формирования брачного союза: первый - это «ранний прямой» брак (без предварительного сожительства), второй - «поздний прямой» брак, третий - ранний брак с предшествующим сожительством, четвертый - поздний брак с предшествующим сожительством, пятый - продолжительное сожительство, не перерастающее в брак. В первых двух поколениях в большинстве стран доминировала практика вступления в «прямой» брак (как в поздний, так и в ранний), жизненные пути были еще достаточно однородными. Картина, наблюдаемая в поколении 1965-1974 годов рождения, представляет наибольший интерес. «Прямой» брак остается одной из самых распространенных практик формирования союза только в Румынии, Польше, Болгарии, Литве, Испании и Италии. Норвегия, Франция, Нидерланды, Австрия, Великобритания, Бельгия, США, Эстония и Россия характеризуются распространенностью сожительств, предшествующих как раннему, так и позднему, браку. Однако Норвегия, Франция, Нидерланды и Эстония отличаются, в дополнение к этому, высокой долей сожительств как самостоятельных союзов, не перерастающих в браки (более 25\%).

Неравномерное распространение изменений в матримониальном поведении в разных странах может быть объяснено их неодновременным включением в процесс демографической модернизации, а также различиями в историко-культурных и политических особенностях стран [Демографическая модернизация России 2006], в т.ч. в традиционно существовавшем в стране типе брачности, профиле ценностей населения, режиме семейной политики.

Традиционно существовавший в стране тип брачности. Одним из первых начал изучать брачность в межрегиональном контексте Хайнал [Hajnal 1965]. Он указал, что на протяжении нескольких последних столетий исторический тип брачности в Европе отличался от типов, существующих в других регионах мира. За пределами Европы он наблюдался лишь в странах, которые были населены выходцами из нее и входили в состав западной цивилизации: США, Канада, Австралия. Брачность там была поздней, процент 
окончательного безбрачия рекордно высоким для того времени (10-15\% для мужчин и $15-$ $20 \%$ для женщин). Хайнал провел границу между двумя разными типами формирования семей по линии Санкт-Петербург (Россия) - Триест (Италия). Западнее проведенной линии господствовал «европейский тип брачности» (далее в работе «западноевропейский»), а восточнее нее брачность была более ранней и универсальной, а признаки Второго демографического перехода начали проявляться позднее, чем в западноевропейских странах (далее в работе «восточноевропейский» тип брачности) [Puur et al 2012].

Профиль ценностей населения. Согласно концепции демографической системы [Вишневский 1982], демографическое равновесие поддерживается взаимодействием трех видов демографического поведения: матримониального, репродуктивного и сексуального. Чем теснее связаны между собой эти три вида поведения, тем меньше у индивида возможностей настраивать свой жизненный путь. До наступления Второго демографического перехода жизнь человека рассматривалась как цикл, в котором каждому возрасту соответствовал предписанный набор ролей. С наступлением демографической модернизации, жизнь стала восприниматься уже как путь с множественным выбором, доступным индивиду в каждый момент времени вне зависимости от возраста и пола. Соответственно совершается вполне логичный переход от ценностей выживания к ценностям самовыражения [Inglehart, Welzel 2005]. Сожительство как пробный брак теперь играет важную роль, позволяя оценить, насколько партнеры подходят друг другу.

Теория М. Вебера об идеальных типах социального действия позволяет предположить, что при переходе к современному типу воспроизводства населения совершается и переход от ценностно-рационального типа действия к целерациональному [Вебер 1990], действия людей, в т.ч. и в матримониальной сфере, становятся рациональными, более гибкими, менее контролируемыми со стороны системы [Вишневский 2009]. Проверить это предположение можно с помощью уже упомянутой выше работы Р. Инглхарта и К. Вельцеля [Inglehart, Welzel 2005]. Ее авторами был проведен анализ данных Всемирного исследования ценностей (World Values Survey), посвященный взаимосвязи между модернизацией и изменением ценностей [Inglehart, Welzel 2005]. Они рассматривали два континуума: выживание-самовыражение и традиции-рациональность (светскость). К ценностям выживания относятся экономическая и физическая безопасность, материальные ценности, нетерпимость к инакомыслию, низкая оценка свободы и прав человека, готовность принять авторитаризм, склонность к вере во всемогущество науки и техники; ценности самовыражения - это высокие оценки личности, свободы, прав человека, материальных благ, успеха, озабоченность экономикой, равенством полов. К традиционным ценностям причисляют религиозность, ориентацию на крепкую семью, почтение к власти, социальный конформизм, отсутствие готовности участвовать в открытых политических конфликтах; к рациональным (светским) - рациональное поведение, установка на достижение личного успеха, незначительная роль религии.

В результате авторами была построена карта ценностных ориентаций с несколькими кластерами. К кластеру стран, население которых максимально оценивает важность рациональности и самовыражения, относятся Швеция, Германия, Норвегия, Швейцария, Финляндия, Нидерланды, Франция, Великобритания, Австралия, Новая Зеландия, Канада, США. К кластеру стран, население которых высоко оценивает важность рациональности и 
выживания относятся Китай, Россия, Южная Корея, Болгария, Япония, Украина и др. К кластеру стран, население которых высоко оценивает важность традиций и выживания относятся страны Южной Азии, Латинской Америки и Африки. По мере модернизации страны постепенно и последовательно перемещаются из квадрата важности «выживаниетрадиции» в «самовыражение-рациональность». Именно страны первой группы задают темп изменений в матримониальном поведении в Европе, за ними следуют страны второй и третий групп.

Режим семейной политики. Многие авторы, в том числе, Л. Хантейрис, Г. ЭспингАндерсен и другие отмечают наличие взаимосвязи между режимами социальной семейной политики государства и процессами трансформации семьеобразующего поведения [Hantaris 2004; Esping-Andersen 2009; Mills, Blossfeld 2013; Елизаров 2013]. Традиционно исследователи придерживаются классификации, предложенной Г. Эспинг-Андерсеном, который выделял три основных режима, исходя из степени декоммодификации (степени зависимости от рынка труда), наличия универсалистского статуса гражданина, а также наличия соглашений между институтами семьи, государства и рынка [Esping-Andersen 1990].

Первый тип режима - социал-демократический. Он существует в Дании, Норвегии, Финляндии и Швеции и характеризуется высокими налогами, эффективным перераспределением доходов, высоким процентом женщин на рынке труда (с возможностью частичной занятости), относительным гендерным равенством на рабочих местах и при выполнении домашних обязанностей, высоким уровнем жизни граждан. Этот режим способствует включенности молодых мужчин и женщин как в семейную, так и в трудовую сферы жизни.

Для второго, консервативного, режима, признаки которого можно найти в Австрии, Бельгии, Германии, Италии, Испании и некоторых других странах, характерен относительно низкий процент женщин на рынке труда, зависимость от социальных взносов, а не от налогов, умеренное перераспределение доходов, сравнительно высокий уровень безработицы среди молодежи и, соответственно, меньшая уверенность в завтрашнем дне. Он ориентирован, скорее, на традиционный тип семьи, где большую часть дохода семьи обеспечивает мужчина. Влияние этого режима на процесс формирования семьи выражается в откладывании вступления в брак и рождения ребенка из-за ограниченных возможностей женщин совмещать семейную жизнь и карьеру.

Третий режим, либеральный, можно встретить в Великобритании, Швейцарии, США, Канаде. Его атрибутами можно считать низкий уровень государственных расходов на социальную защиту, высокий уровень неравенства в обществе. Пассивная политика государства в сфере семьи и рынка труда способствует тому, что молодежь не спешит обзаводиться семьей, предпочитая вклад в образование и развитие карьеры.

Безусловно, описанная выше классификация не является универсальной, поскольку не покрывает режимы социальной политики многих стран, в том числе, и России. В связи с этим, М. Миллс и Х. Блоссфилд добавили в список еще один режим, который можно встретить в посткоммунистических странах [Mills, Blossfeld 2013]. По своим характеристикам этот режим схож с консервативным, но отличается более скромным 
уровнем жизни граждан и достаточно низким уровнем доверия к государственной системе. В последние годы в странах четвертой группы наблюдается стремление государства к стимулированию рождаемости и ориентированию граждан на создание крепкой семьи.

Приведенные исследования показывают, что от традиций, культуры, курса социальной политики государства, действительно, в определенной мере может зависеть, как индивиды формируют свои жизненные пути, поэтому упомянутые выше индикаторы войдут в модель исследования.

\section{Уровень социальных связей и социальных сетей (мезоуровень)}

Трансформация моделей формирования семьи происходит в ответ на изменение ценностей, которые проявляются в распространении нового образа мышления, направленного на самореализацию, постоянное саморазвитие, свободу самостоятельно принимать решения относительно вступления в союз того типа, который предпочитает сам индивид, в условиях отсутствия давления со стороны его окружения. Как писал один из авторов теории Второго демографического перехода, Рон Лестег: «Эпоха растущего религиозного и политического контроля над индивидуальной жизнью человека, которая с такой жестокостью утвердилась на Западе со времен Реформации и Контрреформации, и которая длилась до второй половины XX века, пришла к концу» [Цит. по: Демографическая модернизация России 2006: 138]. Как показываю исследования, представленные в данном подразделе, социальное давление все равно присутствует, но оно сместилось в сторону людей, стандартам поведения которых человек подражает (референтная группа).

Социологи Гаулт-Шерман и Дрепер провели исследование, целью которого было выявление связи между религиозной приверженностью и вступлением в сожительства в США [Gault-Sherman, Draper 2012]. Их модели пространственной регрессии (разделение страны на «юг» и «не юг») позволили выявить статистически значимую обратную связь между приверженностью к объединению со строгим соблюдением евангельских заповедей и долей сожительствующих в числе представителей этого объединения. Выявленный эффект сильнее среди представителей христианских конфессий, живущих на юге США. Авторы делают вывод, что люди, как существа социальные, ориентируются в выборе стратегии своего поведения на ценности и убеждения представителей референтной группы, конструируя в своём сознании их реакцию на свои действия. Это во многом касается брачно-партнерского поведения, которое трудно скрыть от окружающих. Иными словами, данное исследование показывает, что для американской пары до сих пор важно, что о них скажут соседи и как они оценят их поведение с точки зрения морали и религии.

Исследование, проведенное в Испании и Италии, также показало, что риск вступить в сожительство выше для нерелигиозных, в то время как религиозные предпочитают брак без предварительного сожительства [Pereiro, Pace, Didonna, 2014]. В России религия является причиной выбора брака, а не сожительства для тех, кто причисляет себя к верующим, причем очень часто регистрация брака - промежуточная стадия на пути к церковному браку [Исупова 2015].

Гербером и Бёрманом с помощью метода анализа наступления событий было выявлено, что фактором выбора в пользу сожительств, а не браков, также выступает тип 
населенного пункта проживания индивида. Жители мегаполисов подвержены большему риску вступления в сожительства, нежели те, кто проживает в сельской местности [Gerber, Berman 2010]. Это связано с неравномерностью распространения модернизированных установок относительно матримониального поведения. Первыми их подхватывают именно жители городов: здесь больше анонимности и свободы выбора в организации жизненного пути.

\section{Уровень индивида и/или пары (микроуровень)}

Представленные в данном подразделе исследования по выявлению детерминант выбора матримониального союза, связанных с принятием решений самим индивидом или обоими партнерами, акцентируют внимание на особенностях предшествующей союзу траектории взросления, уровне образования, владении недвижимостью для совместного проживания, статусе занятости партнеров, их финансовой независимости.

Анализируя работы о факторах микроуровня, нельзя обойти стороной международное сравнительное исследование, проведенное под руководством ПереллиХаррис. В проекте принимали участие представители девяти стран, в каждой из которых было проведено несколько фокус-групп отдельно с мужчинами и женщинами с разным уровнем образования [Perelli-Harris et al 2014]. Первым фактором является возраст вступления в союз. Выявлено, что на раннем этапе взрослой жизни, то есть сразу после 18 лет, незарегистрированные союзы в Европе и Австралии гораздо предпочтительнее зарегистрированных [Perelli-Harris et al 2014]. Это объясняется нежеланием молодых людей (особенно женщин) отвлекаться от саморазвития, быть финансово зависимыми, а также отсутствием готовности брать на себя обязательства. С точки зрения теории Второго демографического перехода, молодежь подходит к поиску партнера для брака избирательнее, чем это делали представители более старших поколений в их возрасте; требования к партнеру повышаются, поиск подходящего спутника жизни может затянуться, что отодвигает возрасты вступления в брак [Mills, Blossfeld 2013].

В России некоторые женщины не хотят вступать в зарегистрированный союз, пока они молоды, поскольку такой союз их «закабалит и остановит» [Исупова 2015: 159]. Тем не менее, к 30-35 годам даже такие женщины вступают в союз или начинают мечтать о семье, поскольку в этом возрасте быть не замужем «уже как-то стыдно» [Исупова 2015: 160]. Для российских мужчин не было выявлено критической точки на оси возраста, после которой их начинают посещать мысли о браке.

Серьезное давление в вопросах брачно-партнерского поведения оказывается на молодых россиян со стороны родственников [Исупова 2015]. Матримониальный опыт друзей и родных может оказывать тот же эффект, что и собственный: если индивид был свидетелем их неблагополучного опыта, он может временно воздержаться от вступления в союзы [Исупова 2015]. Этот эффект нашел подтверждение и в исследовании матримониального поведения в Испании и Италии [Pereiro, Pace, Didonna 2014]: модель показала, что риск вступления в сожительство выше для женщин, выросших в неполной семье, в то время как те, кто видел в родителях пример благополучного брака, предпочитают зарегистрированный союз в качестве первого. Кроме того, важно, как и когда произошло отделение девушки от родительской семьи. Покидание родительского дома, 
связанное с получением образования или началом трудовой карьеры, увеличивает риск вступления в сожительство. Риск вступить в брак как первый союз выше для женщин, не отделившихся от родителей.

Еще одной детерминантой этого уровня является беременность первым ребенком. О.Г. Исупова называет его дополнительным стимулом вступления в брак, определяющим только сроки события, а не сам факт, поскольку те, чьи нормативные установки не предполагают возможности регистрации отношений, не вступят в союз такого типа даже при рождении ребенка. Результаты количественного исследования с помощью модели конкурирующих рисков, построенной только для женщин из Италии и Испании и посвященной выявлению различий между браком без предварительного сожительства и сожительством [Pereiro, Pace, Didonna 2014], не противоречат этому утверждению: зачатие увеличивает риск вступить в любой матримониальный союз, но большее предпочтение в обеих странах до сих пор отдается браку.

Какая-то часть российских женщин испытывает опасение, что заключение брака может испортить благополучное сожительство, поэтому они предпочитают просто регистрировать ребенка с партнером, который в таком случае обладает теми же правами и обязанностями, что и муж [Исупова 2015]. При отсутствии уверенности в партнере или наличии предыдущего негативного опыта женщина может зарегистрировать ребенка исключительно на себя (это позволяет избежать многих проблем, например, при вывозе ребенка в другую страну). Для некоторых мужчин рождение ребенка может стать ключевой причиной для заключения брака, поскольку дети - это единственное, что мужчине проблематично получить без женщины [Исупова 2015].

Гербер и Бёрман выяснили, что риск вступления в незарегистрированный союз выше для мужчин со средним или профессиональным образованием, чем для тех, кто получил или еще получает высшее образование. В противоположность этому, женщины со средним или профессиональным образованием менее склонны к вступлению в сожительство, чем более образованные женщины [Gerber, Berman 2010].

В уже упомянутом исследовании Перейро [Pereiro, Pace, Didonna 2014] изучалось влияние на матримониальное поведение финансовой независимости женщин, индикатором которой выступал их статус занятости. В случае Испании, риск занятых женщин вступить в любой союз выше, чем у безработных, причем риск вступить в сожительство превышает риск вступить в брак как первый союз. В случае Италии, статус занятости женщины не коррелирует с выбором союза. Статус занятости мужчины не менее важен чем статус женщины при выборе типа брачно-партнерского союза. Это доказывает исследование Букоди, посвященное выявлению связи между наличием стабильной работы и матримониальными траекториями британских мужчин [Bukodi 2012]. Отсутствие стабильности в начале трудовой траектории увеличивает риск вступления в сожительство, но не в брак в качестве первого союза. Низкий уровень заработной платы увеличивает риск того, что сожительство не перерастет в брак.

При проведении фокус-групп в России было выяснено, что в отношениях, где заработок партнера невысок, женщина может пытаться мотивировать мужчину зарабатывать больше с помощью обещания дать согласие стать его женой. В то же время, 
было замечено, что многие женщины и мужчины, обладающие частной собственностью, особенно недвижимостью, или занимающие высокооплачиваемые должности, могут предпочитать сожительство браку, поскольку это является гарантией того, что партнер в случае разрыва не сможет посягнуть на их имущество [Исупова 2015].

Таким образом, проведенные качественные и количественные исследования показывают, что значимыми факторами матримониального поведения выступают:

- на макроуровне: исторически сформировавшийся в стране тип брачности, система ценностей граждан, режим семейной политики государства;

- на мезоуровне: степень религиозности, тип населенного пункта, референтная группа;

- на микроуровне: возраст вступления в союз, предыдущий биографический опыт (или опыт близких людей), предшествие зачатия вступлению в союз, обстоятельства покидания родительского дома, уровень образования, владение недвижимостью для совместного проживания, статус занятости партнеров и их финансовая независимость.

Влияние всех трех групп факторов по-разному сказывается на матримониальном поведении мужчин и женщин и зависит от их принадлежности к разным поколениям. Гендерные роли постепенно меняются. Хотя женщина до сих пор в большой степени воспринимается сквозь призму выполнения ею социальных ролей матери и жены [Исупова 2015], эти роли занимают в ее жизни гораздо меньше места, чем прежде, возросшая значимость образования и профессиональной деятельности способствует тому, что женщина обрела большую независимость и стала стремиться к самоактуализации. Для представителей обоих полов создание семьи отодвинулось на более поздние возрасты, изменился и характер семейных отношений.

Принадлежность индивида к тому или иному поколению, в свою очередь, отражает связь между детерминантами разных уровней. Период рождения, а, следовательно, и социализации, связан с тем, какие именно установки относительно матримониального поведения сформирует индивид. То, что окружает нас, пока мы растем, воспринимается нами как данность, условия, в которых функционирует семья и формируются союзы в момент нашей первичной социализации, могут стать для нас той моделью поведения, которой мы будем придерживаться и захотим воспроизвести впоследствии.

Изменения в матримониальном поведении происходят во всех странах. Используя имеющиеся в нашем распоряжении данные, попытаемся ответить на вопрос о том, как эти изменения, происходящие в России, соотносятся с тенденциями, наблюдаемыми в других европейских странах.

\section{ДАННЫЕ И МОДЕЛИ ИССЛЕДОВАНИЯ}

\section{Данные}

Динамику изменения брачности и разводимости в России в сравнении с другими странами можно проследить по данным международных сравнительных выборочных обследований, которые в последние десятилетия объединяют все большее число стран. Одним из самых 
известных международных обследований, в которых принимала участие Россия, является выборочное ретроспективное лонгитюдное обследование «Родители и дети, мужчины и женщины в семье и обществе» (РиДМиЖ/RusGGS), оно было частью международной программы ЕЭК ООН «Поколения и Гендер» («Generations and Gender Survey» или сокращенно - GGS). В дальнейшем для сравнения России с другими странами мы используем данные именно этого обследования, поскольку оно является репрезентативным для каждой из стран-участниц и, с учетом унифицированности программы, позволяет проводить межстрановые сравнения.

Трансформация брачно-партнерского поведения россиян была рассмотрена в контексте изменения брачности и разводимости в десяти европейских странах, по которым доступны данные второй волны обследования (Австрия - 3912 человек, опрошенных в 2008 г., Болгария - 9344 человека, опрошенных в 2007 г., Венгрия - 10641 человек, опрошенных в 2008 г., Германия - 3212 человек, опрошенных в 2008 г., Грузия - 8292 человека, опрошенных в 2009 г., Италия - 6476 человек, опрошенных в 2007 г., Литва 2292 человека, опрошенных в 2009 г., Нидерланды - 6090 человек, опрошенных в 2006 г., Россия - 7780 человека, опрошенных в 2007 г., Франция - 6533 человека, опрошенных в 2008 г. и Чехия - 3149 человека, также опрошенных в 2008 г.).

Все респонденты были разделены на тринадцать пятилетних когорт 1924-1989 гг. рождения. Четыре самые молодые когорты на момент опроса еще не достигли достаточной зрелости (возраста 35 лет), поэтому выводы, относящиеся к этим когортам, следует считать предварительными.

Анализ детерминант мезо- и микроуровней основан на данных, содержащихся в базе данных обследования РиДМиЖ. Она включает в себя три волны (таблица 1).

Таблица 1. Основные характеристики базы данных обследования РиДМиж

\begin{tabular}{lcc}
\hline Год проведения & & Панель: 2004, 2007, 2011 \\
Выборка & 4948 человек \\
Охват поколений & & $1935-1984$ гг. рождения \\
Возраст респондентов & $24-85$ лет \\
Пол & Мужчины & $32 \%$ \\
& Женщины & $68 \%$ \\
Поколение & $1935-1944$ & $16,8 \%$ \\
& $1945-1954$ & $21,4 \%$ \\
& $1955-1964$ & $26,8 \%$ \\
& $1965-1974$ & $21,4 \%$ \\
\hline
\end{tabular}

Источник: Составлено авторами по данным РиДМиЖ (2004, 2007, 2011)

В соответствии с периодами социализации, Ю.А. Левада относит к «советским» поколениям тех, кто родился в 1935-1974 гг., а к «современным»- рожденных в 19751984 гг. [Левада 2015].

Наблюдение за траекториями жизненного пути россиян каждого из анализируемых поколений осуществлялось через окно возраста 15-35 лет. Нижняя граница представляет собой возраст начала взросления и старта репродуктивного поведения. Верхняя была выбрана таким образом, чтобы уравнять шансы представителей всех поколений выборки 
вступить в союз первой очередности, избежав влияния нетипично высоких возрастов вступления в первые союзы у представителей старших поколений. Респонденты, у которых первые события наступили после 35 лет, не исключались из анализа, исключались лишь события, наступившие после установленной границы. Этого возрастного окна достаточно для отслеживания параметров наступления первых союзов, поскольку у россиян они все еще сосредоточены в достаточно раннем возрасте в сравнении с западноевропейскими странами [Perelli-Harris, Lyons-Amos, 2015].

\section{Моделирование вступления в первые матримониальные союзы}

Прежде чем перейти непосредственно к анализу факторов вступления в союзы, необходимо смоделировать возможные варианты матримониального поведения (рисунок 1). Как видно из рисунка, здесь возможны следующие сценарии.

Сценарий 1 - Отсутствие союзов. После начала наблюдения (15 лет) и до его окончания матримониальный статус человека не изменился. Это означает, что человек по тем или иным причинам живет один (к этому сценарию может относиться отсутствие отношений, отношения, длившиеся менее трех месяцев, или LAT-партнерства (от английского "living apart together" - живущие вместе раздельно), в которых пары имеют длительные отношения, но живут отдельно друг от друга). Две последние категории не рассматриваются в рамках данной работы.

Сценарий 2 - Сожительство как первый союз. В рамках данного исследования важен факт выбора незарегистрированных отношений для начала совместного проживания. Среди респондентов РиДМиЖ доля сделавших такой выбор составляет 29,2\%.

Следует отметить, что такое сожительство может перерасти в брак. В этом случае можно говорить, что сожительство было только промежуточным звеном на пути к браку. Среди респондентов, следовавших Сценарию 2, доля носителей этого статуса составляет 77\%. Первое сожительство также может выступать самостоятельным союзом, если пара принимает решение не вступать в брак. В панельной части трех волн обследования «РиДМиЖ» в 23\% случаев сожительство либо не завершилось на момент опроса третьей волны, либо завершилось, но за ним не последовало официального брака.

Сценарий 3 - Брак как первый союз. Среди респондентов РиДМиЖ доля тех, кто вступил в первый брак, минуя стадию партнерства, составляет 63,4\%. 


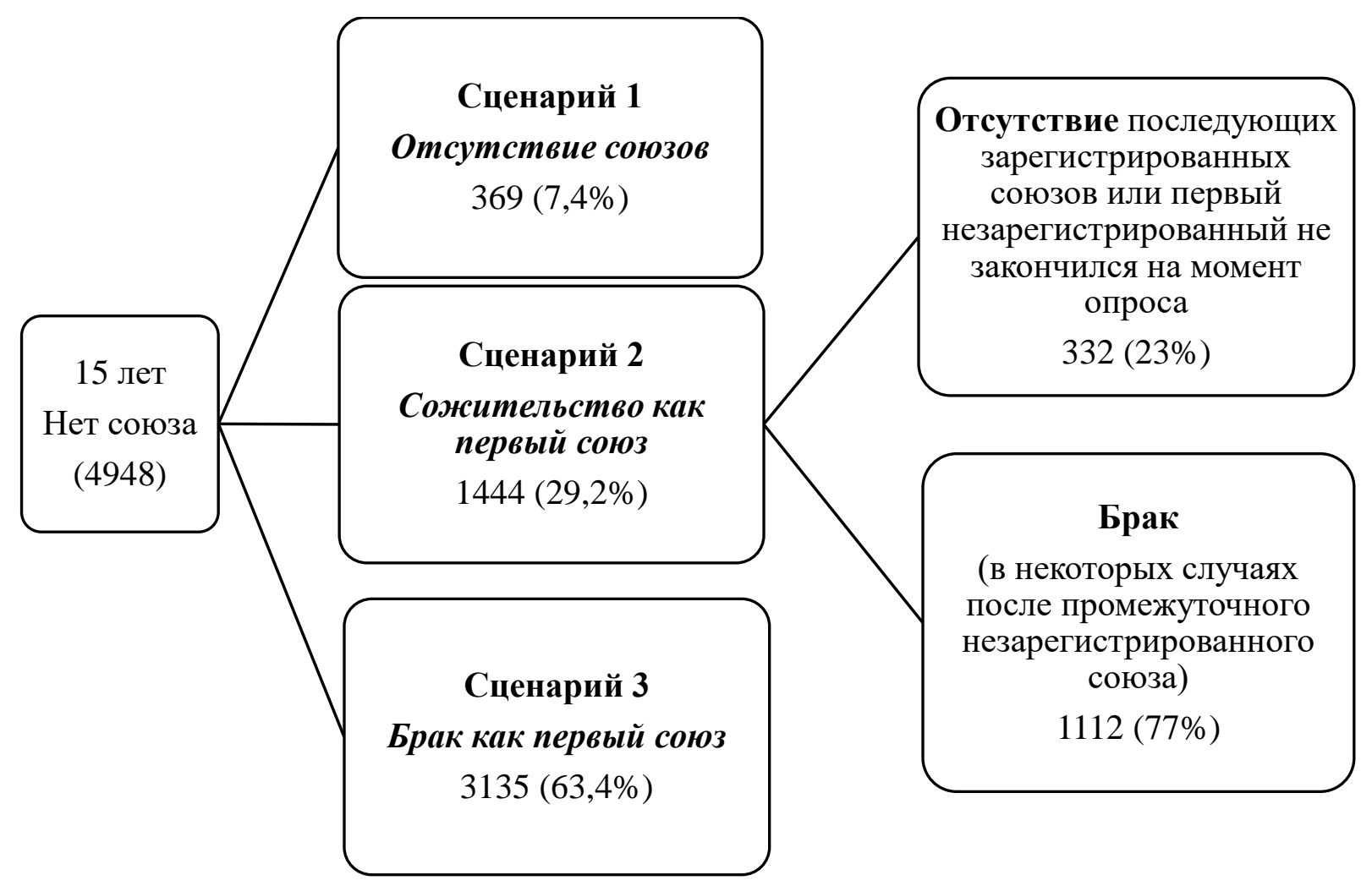

Рисунок 1. Первые матримониальные события россиян

Источник: Составлено авторами по данным РиДМиЖ (2004, 2007, 2011)

На рисунке 2 представлено начало матримониального поведения (Сценарии 1-3) респондентов РиДМиЖ в разрезе пола и поколений.

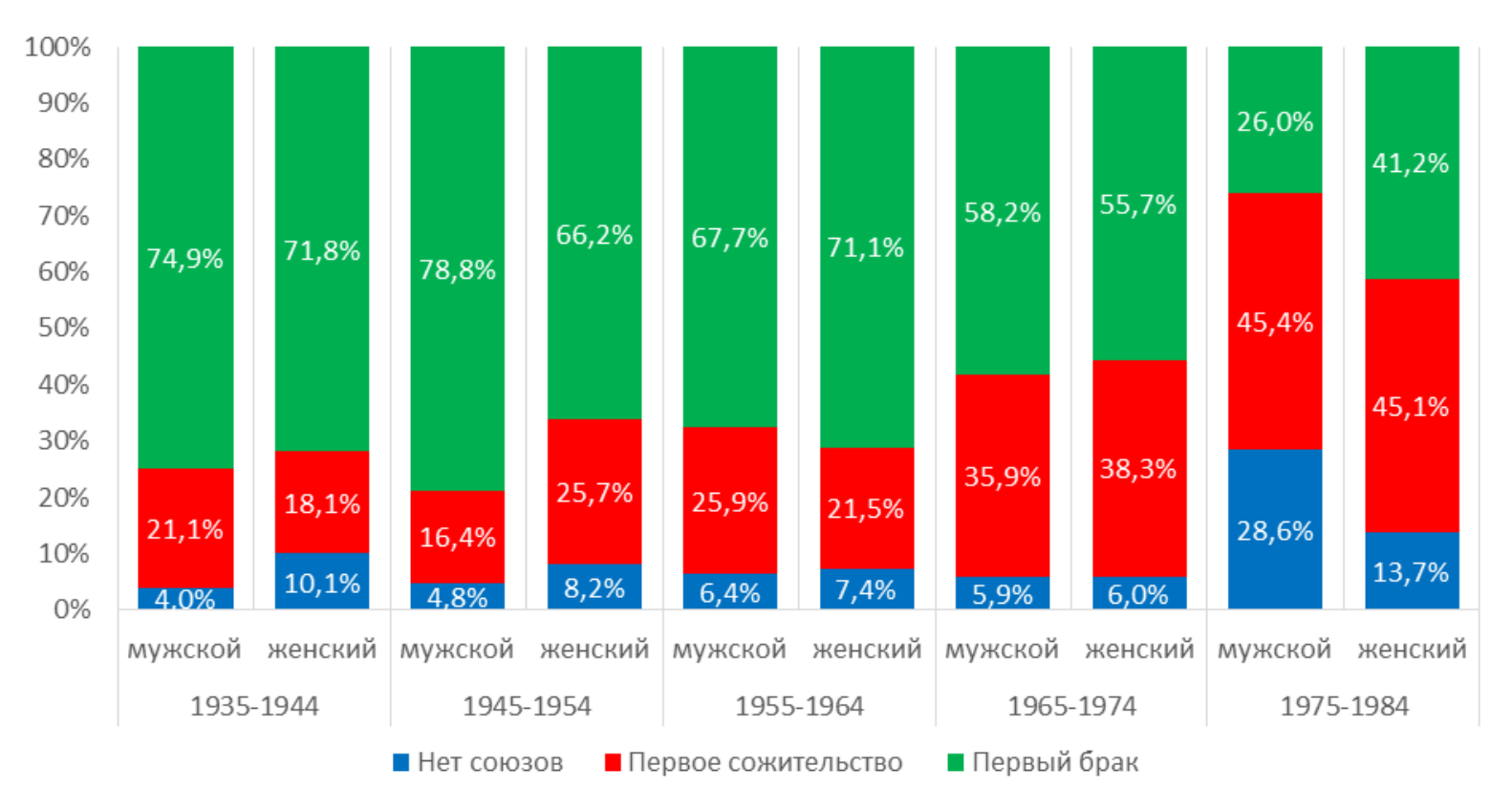

Рисунок 2. Распределение мужчин и женщин разных поколений по первому матримониальному статусу

Источник: Составлено авторами по данным РиДМиЖ (2004, 2007, 2011) 
Из рисунка 2 следует, что брак как первый союз становится все менее популярным среди молодых поколений россиян, уступая место первому сожительству (которое более чем в половине случаев приводит к первому браку), при этом доля не состоящих в союзе возрастает только из-за эффекта календаря: молодые поколения еще просто не успели обзавестись партнером.

Чтобы понять, какими характеристиками обладают те, кто выбирает сожительство или брак в качестве первого союза, нами построены две группы моделей.

1. Дерево классификации. Оно необходимо для разведывательного анализа и отбора значимых предикторов для второй группы моделей. В качестве зависимой переменной выступали матримониальный статус респондента в соответствии с двумя последними описанными выше сценариями (1 - сожительство как первый союз, 2 - брак как первый союз). Независимыми переменными выступали детерминанты мезо- (тип населенного пункта проживания), и микроуровней (возраст вступления в союз, предшествие зачатия вступлению в союз, матримониальный опыт родителей, обстоятельства покидания родительского дома и начала работы, уровень образования).

2. Логистическая регрессия. С её помощью были выявлены риски вступить в сожительство или брак с учетом переменных, которые были определены как значимые по итогам первой модели. Были построены отдельные модели для мужчин и женщин разных поколений.

В вопроснике РиДМиЖ есть информация о религиозности респондентов, их статусе занятости, жилищных условиях и удовлетворенности жильем, однако эти переменные не могут быть использованы в рамках данного исследования, поскольку дают информацию о респондентах на момент опроса, в то время как ситуация на момент вступления в союз могла быть совершенно иной. Можно возразить, что уровень образования респондента на момент опроса и на момент вступления в союз тоже может различаться, однако предварительный анализ показал, что больше $90 \%$ респондентов вступили в союз уже после получения образования наивысшего уровня или не более чем за год до окончания обучения, поэтому данную переменную мы не исключили из анализа.

\section{АНАЛИЗ: ПРОВЕРКА ДЕТЕРМИНАНТ}

\section{Межстрановые различия и детерминанты макроуровня}

С помощью кластерного анализа страны были условно разделены на те, где изменения в брачно-партнерском поведении ярко выражены и те, где изменения менее заметны. Эти изменения рассмотрены в разрезе следующих переменных: исторический тип брачности, режим социальной семейной политики, профиль ценностей населения, среднее число партнеров в брачно-партнерской биографии к моменту наблюдения, доля тех, у кого имел место первый брак, доля переживших развод, доля вступивших во второй брак (таблица 2). Ниже параметры матримониального поведения по странам представлены во всех этих разрезах с акцентом на России. 
Таблица 2. Историко-культурные особенности стран и некоторые параметры матримониального поведения их населения

\begin{tabular}{|c|c|c|c|c|c|c|c|}
\hline Страна & $\begin{array}{c}\text { Тип } \\
\text { брачности* }\end{array}$ & $\begin{array}{c}\text { Режим } \\
\text { семейной } \\
\text { политики** }\end{array}$ & $\begin{array}{c}\text { Профиль } \\
\text { ценностей } * * *\end{array}$ & $\begin{array}{l}\text { Ср. число } \\
\text { партнеров }\end{array}$ & $\begin{array}{c}\% \\
\text { первых } \\
\text { браков }\end{array}$ & $\begin{array}{c}\% \\
\text { первых } \\
\text { разводов } \\
\end{array}$ & \begin{tabular}{|c|} 
\\
повторных \\
браков \\
\end{tabular} \\
\hline Австрия & 3. & K. & $\mathrm{P}-\mathrm{C}$ & 2,2 & 48,7 & 8,8 & 8,0 \\
\hline Германия & 3. & K. & $\mathrm{P}-\mathrm{C}$ & 1,6 & 61,2 & 11,2 & 5,3 \\
\hline Нидерланды & 3. & K. & $\mathrm{P}-\mathrm{C}$ & 1,1 & 63,2 & 12,0 & 5,2 \\
\hline Франция & 3. & $\mathrm{~K}$. & $\mathrm{P}-\mathrm{C}$ & 1,7 & 60,5 & 12,0 & 4,7 \\
\hline Чехия & 3. & $\Pi$. & $\mathrm{P}-\mathrm{C}$ & 1,6 & 59,6 & 13,9 & 8,1 \\
\hline Венгрия & B. & $\Pi$. & $\mathrm{P}-\mathrm{B}$ & 1,2 & 73,6 & 16,2 & 9,0 \\
\hline Литва & C. & П. & $\mathrm{P}-\mathrm{B}$ & 1,6 & 74,5 & 13,3 & 4,6 \\
\hline Россия & B. & П. & $\mathbf{P}-\mathbf{B}$ & 1,7 & 68,5 & 16,7 & 8,7 \\
\hline Италия & C. & K. & $\mathrm{P}-\mathrm{C}$ & 1,4 & 63,5 & 5,7 & 1,5 \\
\hline Болгария & B. & $\Phi$. & $\mathrm{P}-\mathrm{B}$ & 0,8 & 69,9 & 6,0 & 2,4 \\
\hline Грузия & B. & $\Pi$. & $\mathrm{T}-\mathrm{B}$ & 0,9 & 71,1 & 3,2 & 0,8 \\
\hline
\end{tabular}

Источник: Составлено авторами по данным официильного сайта GGP.

Примечания:

* 3. - западноевропейский, В. - восточноевропейский, С. - смешанный.

** К. - консервативный, П. - посткоммунистический, Ф. - формирующийся.

*** $P-C$ : раџиональность-самовыражение, $P-B$ : рациональность-выжсивание, $T$ - В: традиции-

выжнвание.

Данные второй волны GGS подтверждают, что брак перестал быть универсальным и таким устойчивым, как прежде. Люди предпочитают не ограничиваться одним партнером в течение всей жизни. Такие изменения характерны и для стран Западной Европы (Австрия, Германия, Италия, Франции), и для стран Центральной и Восточной Европы (Чехия, Литва), и для России (рисунки 3-5). В указанных странах наблюдается увеличение среднего числа партнеров, к которым могут относиться как супруги, так и сожители, в течение матримониальной биографии. Жители Венгрии, Нидерландов, Болгарии и Грузии придерживаются более традиционной, с точки зрения числа брачных партнеров, модели поведения.

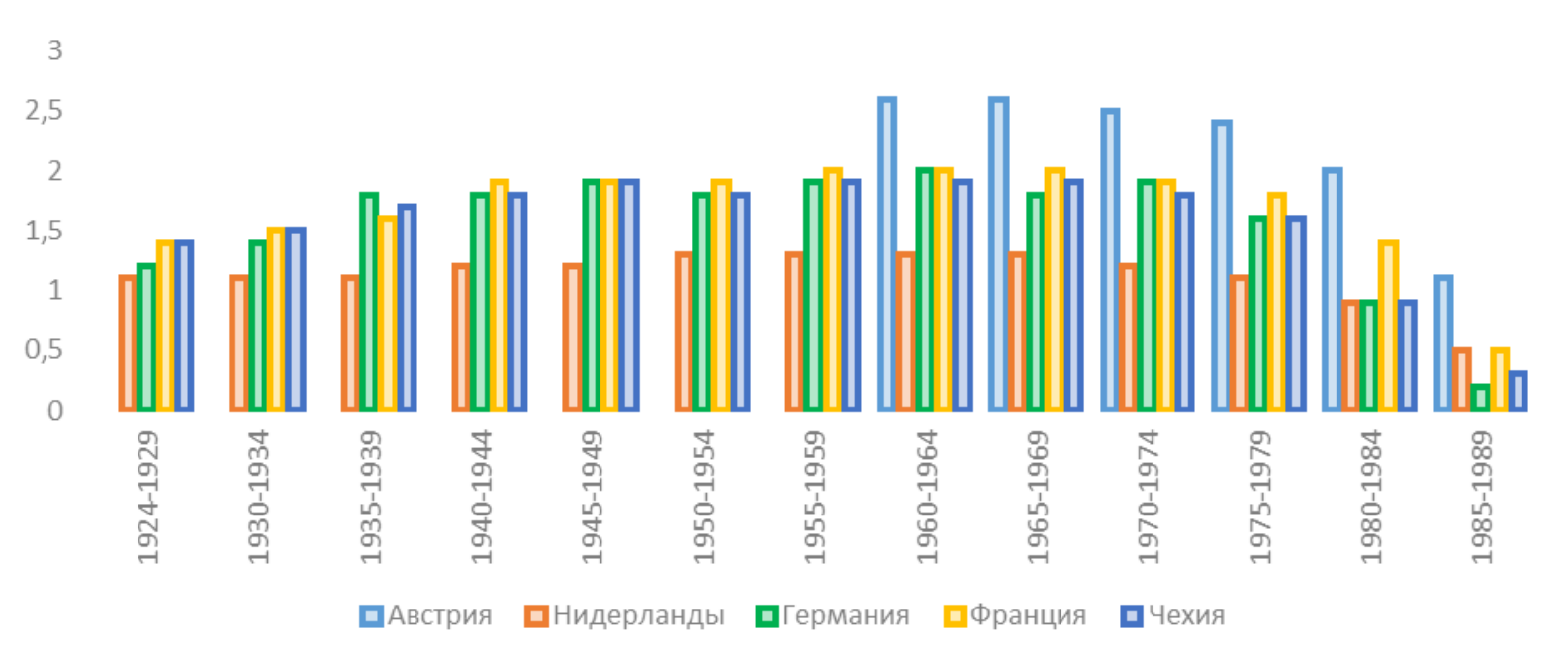

Рисунок 3. Среднее число брачно-партнерских союзов в биографии представителей когорты на момент опроса. Австрия, Нидерланды, Германия, Франция, Чехия

Источник: Составлено авторами по данным GGS (Волна 2) 


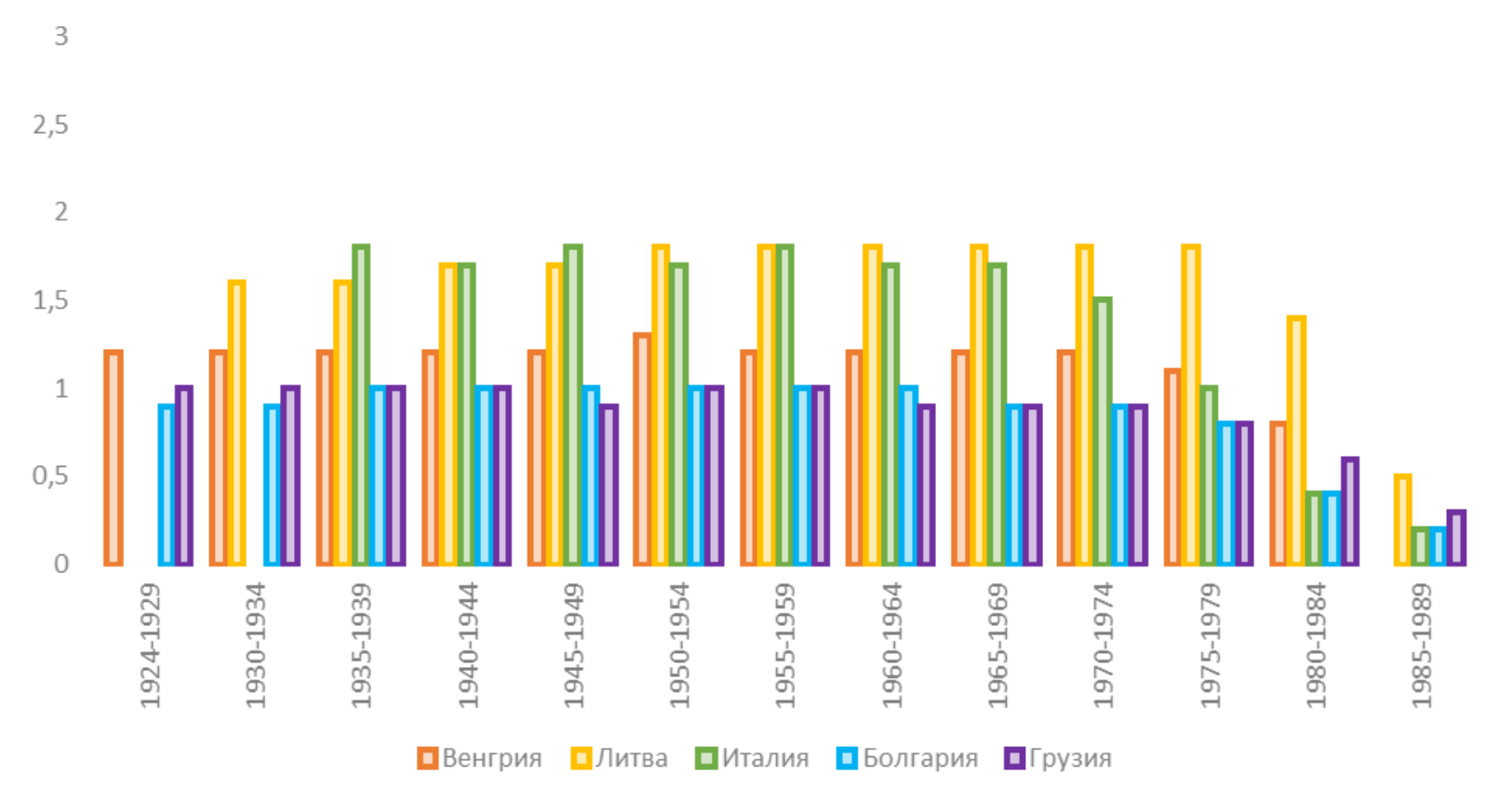

Рисунок 4. Среднее число брачно-партнерских союзов в биографии представителей когорты на момент опроса. Венгрия, Литва, Италия, Болгария, Грузия

Источник: Составлено авторами по данным GGS (Волна 2)

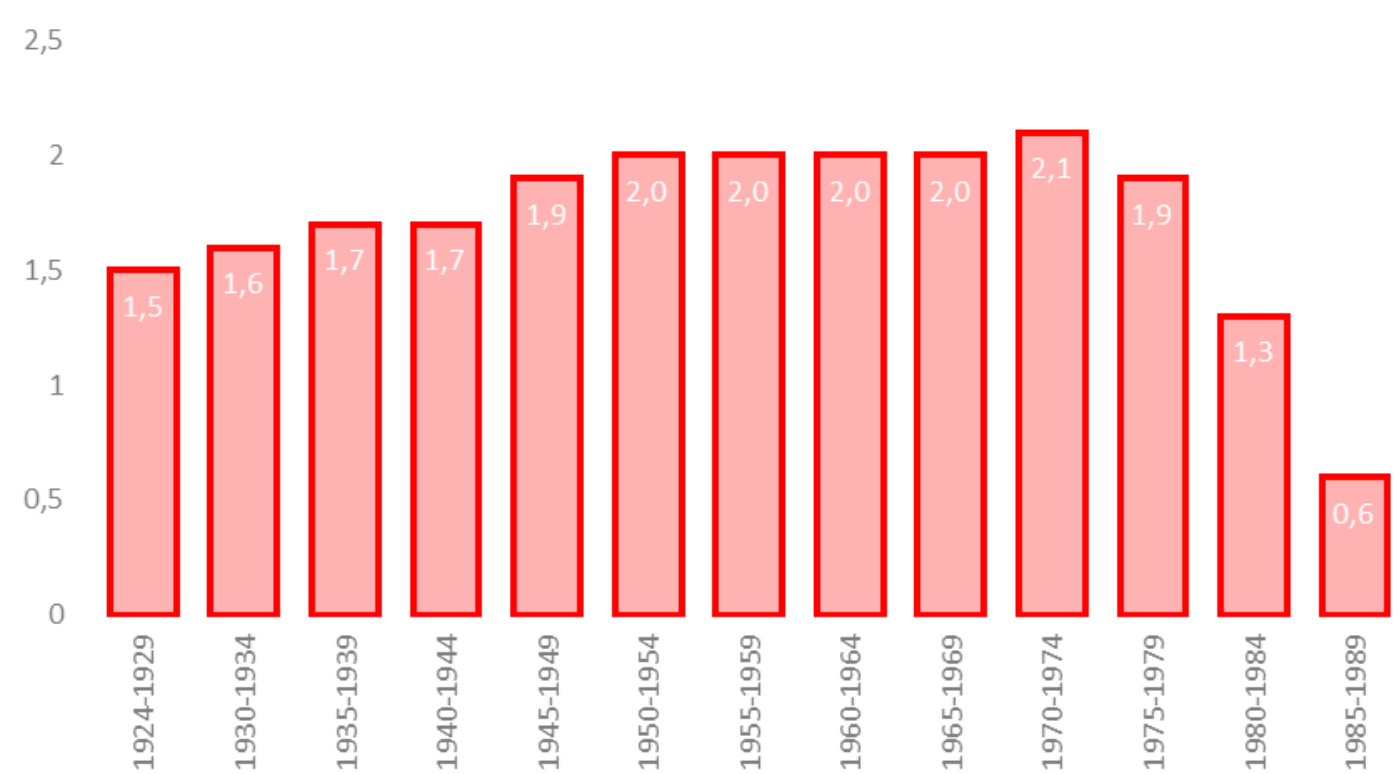

Рисунок 5. Среднее число брачно-партнерских союзов в биографии представителей когорты на момент опроса. Россия

Источник: Составлено авторами по данным GGS (Волна 2)

Данные таблицы 3 более наглядно демонстрируют изменение числа партнеров для разных когорт. Представленные страны можно условно разделить на несколько групп. В Венгрии, Нидерландах, Болгарии, Грузии наблюдается скромное снижение преобладающей доли тех, кто отграничивается только одним союзом в течение жизни. Австрия, Германия, Италия представляют собой группу стран, находящихся на другом полюсе: в них 
минимальна доля людей, имеющих опыт отношений только с одним партнером на протяжении жизни (две трети и более респондентов состояли как минимум в двух союзах). Респонденты из Чехии, Франции и Литвы вступали в один-два союза. Россия отличается от этих стран смещением от преобладания доли тех, кто состоял в отношениях только с одним партнером, к возрастанию доли лиц, вступавших в два или более союза на протяжении матримониальной биографии.

Таблица 3. Распределения по числу партнеров в биографии представителей когорты на момент опроса, \%

\begin{tabular}{|c|c|c|c|c|c|c|c|c|c|c|c|c|c|c|c|}
\hline \multicolumn{16}{|c|}{ Страны, где изменения наиболее заметны } \\
\hline \multirow{2}{*}{$\begin{array}{l}\text { Годы } \\
\text { рождения }\end{array}$} & \multicolumn{3}{|c|}{ Австрия } & \multicolumn{3}{|c|}{ Нидерланды } & \multicolumn{3}{|c|}{ Германия } & \multicolumn{3}{|c|}{ Франция } & \multicolumn{3}{|c|}{ Чехия } \\
\hline & 1 & 2 & $3+$ & 1 & 2 & $3+$ & 1 & 2 & $3+$ & 1 & 2 & $3+$ & 1 & 2 & $3+$ \\
\hline $1924-1929$ & & & & 83,5 & 6,9 & 2,7 & 17,6 & 45,1 & 4,9 & 29,8 & 49,3 & 5,1 & 37,1 & 34,3 & 11,4 \\
\hline 1930-1934 & & & & 81,6 & 10,4 & 1,9 & 13,7 & 58,3 & 3,0 & 29,2 & 52,7 & 4,9 & 30,5 & 47,5 & 6,5 \\
\hline 1935-1939 & & & & 79,1 & 11,7 & 3,8 & 10,0 & 65,8 & 11,4 & 25,7 & 56,5 & 7,5 & 26,1 & 52,1 & 10,9 \\
\hline 1940-1944 & & & & 77,4 & 14,5 & 3,9 & 10,9 & 68,8 & 9,6 & 16,0 & 64,1 & 13,5 & 20,6 & 57,3 & 13,6 \\
\hline $1945-1949$ & & & & 76,8 & 14,2 & 3,9 & 12,0 & 68,0 & 13,1 & 16,8 & 60,7 & 15,5 & 19,2 & 57,7 & 15,7 \\
\hline $1950-1954$ & & & & 67,0 & 19,9 & 7,9 & 9,2 & 70,6 & 10,1 & 16,1 & 61,0 & 16,6 & 18,3 & 57,9 & 14,1 \\
\hline 1955-1959 & & & & 68,4 & 19,5 & 6,7 & 10,5 & 62,1 & 16,9 & 12,0 & 60,2 & 20,8 & 15,6 & 60,6 & 13,8 \\
\hline $1960-1964$ & 6,1 & 63,7 & 27,3 & 67,6 & 19,3 & 7,3 & 7,8 & 67,0 & 15,6 & 14,0 & 60,9 & 19,1 & 16,8 & 59,8 & 14,3 \\
\hline 1965-1969 & 5,6 & 60,0 & 30,8 & 68,9 & 17,0 & 7,9 & 9,9 & 62,1 & 15,6 & 11,1 & 62,7 & 20,8 & 11,4 & 63,9 & 15,7 \\
\hline 1970-1974 & 4,7 & 62,2 & 28,4 & 64,1 & 19,9 & 6,1 & 9,4 & 64,2 & 15,1 & 10,8 & 66,0 & 15,6 & 14,0 & 56,7 & 16,4 \\
\hline $1975-1979$ & 7,1 & 63,4 & 23,8 & 62,7 & 15,9 & 5,2 & 15,6 & 55,3 & 10,6 & 15,6 & 58,8 & 14,0 & 18,1 & 52,3 & 10,0 \\
\hline 1980-1984 & 15,0 & 53,0 & 19,4 & 37,4 & 21,3 & 1,9 & 18,4 & 33,1 & 2,9 & 27,9 & 42,8 & 7,3 & 28,2 & 26,8 & 2,8 \\
\hline $1985-1989$ & 31,5 & 28,6 & 7,0 & 21,4 & 14,3 & 0,0 & 10,0 & 4,0 & 2,0 & 32,9 & 8,1 & 0,9 & 21,1 & 2,6 & 0,7 \\
\hline
\end{tabular}

\begin{tabular}{|c|c|c|c|c|c|c|c|c|c|c|c|c|c|c|c|c|c|c|}
\hline \multicolumn{19}{|c|}{ Страны, где изменения заметны в меньшей степени } \\
\hline \multirow{2}{*}{$\begin{array}{l}\text { Годы } \\
\text { рождения }\end{array}$} & \multicolumn{3}{|c|}{ Венгрия } & \multicolumn{3}{|c|}{ Литва } & \multicolumn{3}{|c|}{ Италия } & \multicolumn{3}{|c|}{ Болгария } & \multicolumn{3}{|c|}{ Грузия } & \multicolumn{3}{|c|}{ Россия } \\
\hline & 1 & 2 & $3+$ & 1 & 2 & $3+$ & 1 & 2 & $3+$ & 1 & 2 & $3+$ & 1 & 2 & $3+$ & 1 & 2 & $3+$ \\
\hline 1924-1929 & 81,2 & 13,8 & 2,2 & & & & & & & 81,3 & 5,4 & 0,0 & 89,8 & 2,7 & 0,0 & 47,9 & 31,0 & 11 \\
\hline & & & 1,6 & ,6 & 1,5 & 5,0 & & & & & & 2 & & 2,0 & 0 & & & \\
\hline & & & 2,2 & 3 & 60,8 & 2,2 & 7,5 & 83,0 & 1,9 & & & & & 8 & 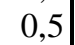 & & 72,2 & \\
\hline 40 & & 15 & 3,8 & 8 & 54,1 & 8,8 & 14,6 & & 2,1 & & 5 & & & 6 & 2 & ,6 & 9 & \\
\hline & & &, 5 & & & 7,7 & 10,2 & & ,0 & & & 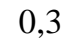 & & 2,8 & 0,0 & 9 & & 20 \\
\hline & & 16 & 5,3 & 16,8 & 66 & 8,9 & 9,4 & $\pi$ & 9 & 85 & & 0 & 90 & 2,5 & 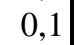 & 1 & 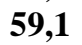 & 20 , \\
\hline 5 & 2 & 17 & 4,5 &, 3 & 65,6 & 9,0 & 9,1 & 77,4 & 4,5 & 8 & 6 & 5 & 1 & 2,5 & d & 14,7 & 60,2 & 21 \\
\hline & & 14 & 5,4 & 9 & 69,5 & 8,0 & 9,5 & 7 & 4 & & & 3 & &, 0 & & 12,7 & 7 & 18 \\
\hline & & & 6,0 & 12,0 & & 6,5 & & & & & & & & & & & & 18 \\
\hline & 6,2 & 10 & ,3 & 9 & 68,4 & 10,0 & 12,4 & 62,8 & ,7 & 79,4 & & 6 & 5 & 3,1 & & , & 60,8 & 23 , \\
\hline 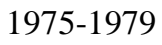 & 56,6 & 18,2 & 6,7 & 10,4 & 75,1 & 5,2 & 24,6 & 37,7 & 0,7 & 67,1 & 4,2 & 0,4 & 72,1 & 1,9 & 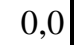 & 12,6 & 61,8 & 16,7 \\
\hline 980 & 42,7 & 15,2 & 3,4 & 17,7 & 55 & 4,8 & 32,7 & 5,5 & 0,3 & 37, & & 0,2 & 4 & 0,7 & 0,0 & 24,7 & 37,8 & 8,3 \\
\hline 85-1989 & & & & 17,9 & 10,6 & 3,3 & 22,6 & 0 & 0,0 & 14,7 & 2,1 & 0,0 & 33,0 & 0,6 & 0,0 & 23,3 & 14,5 & \\
\hline
\end{tabular}

Источник: Составлено авторами по данным GGS (Волна 2).

Доля россиян, когда-либо вступивших в брак, снижается совсем медленно, в отличие от Франции, Италии, Нидерландов (рисунки 6-8). Однако, эта доля и не так высока, как в других странах (несколько «проигрывает» России только Чехия). 


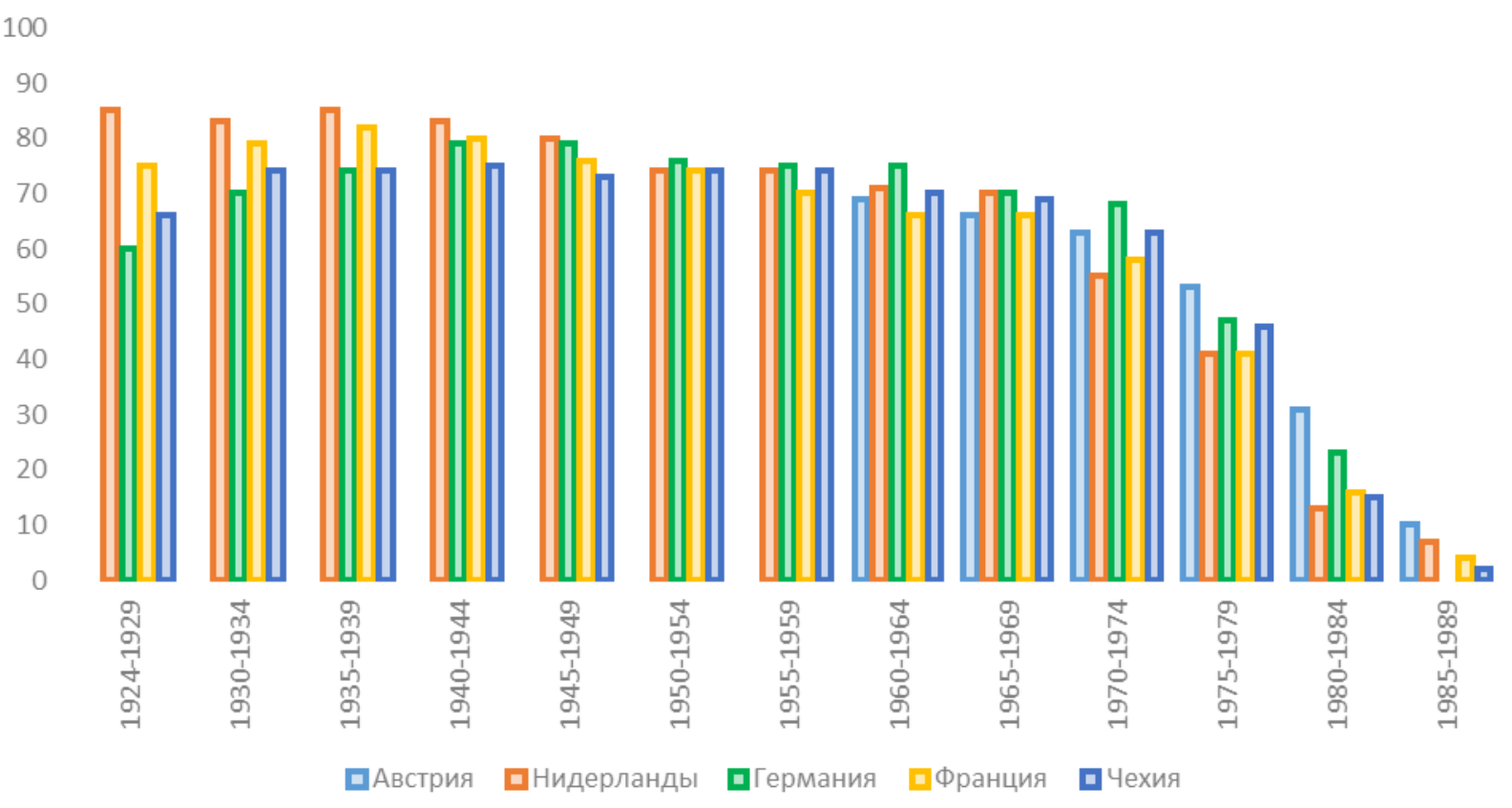

Рисунок 6. Доля вступивших в первый брак к моменту опроса в общем числе респондентов когорты, \%. Австрия, Нидерланды, Германия, Франция, Чехия Источник: Составлено авторами по данным GGS (Волна 2)

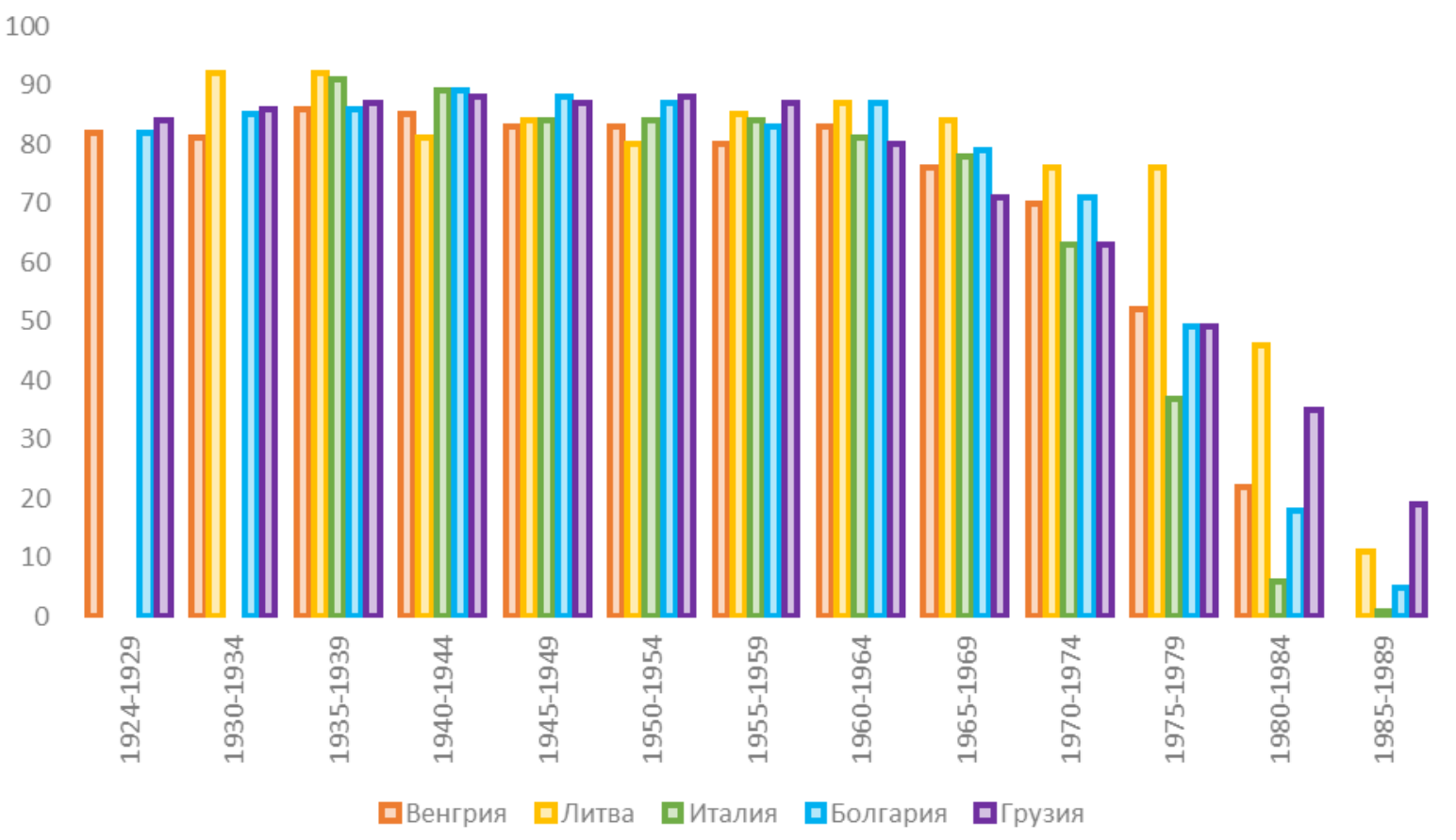

Рисунок 7. Доля вступивших в первый брак к моменту опроса в общем числе респондентов когорты, \%. Венгрия, Литва, Италия, Болгария, Грузия

Источник: Составлено авторами по данным GGS (Волна 2). 


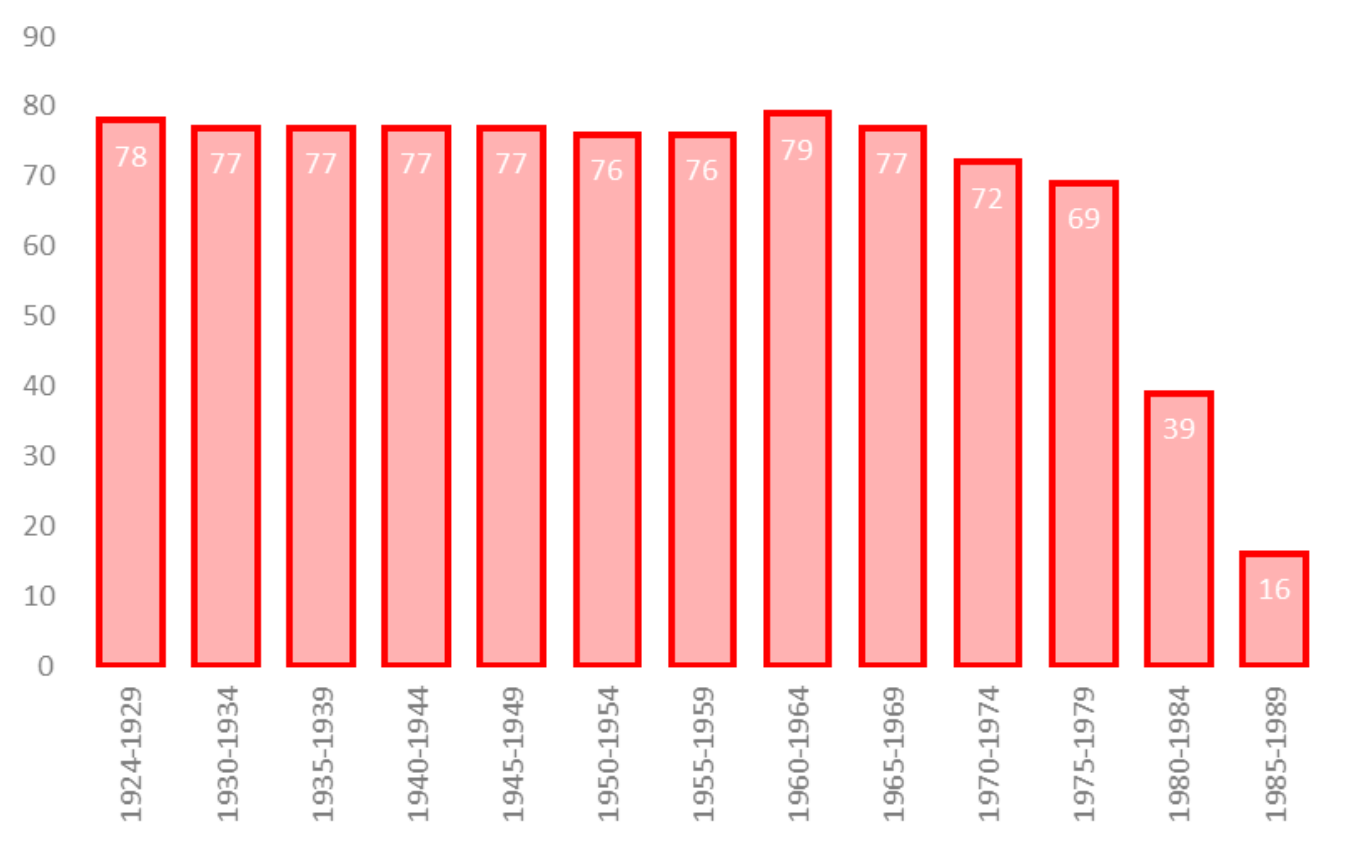

Рисунок 8. Доля вступивших в первый брак к моменту опроса в общем числе респондентов когорты, \%. Россия

Источник: Составлено авторами по данным GGS (Волна 2).

При анализе изменений в матримониальном поведении также следует обращать внимание на долю одиноких. В контексте последних десятилетий к этой категории принято относить не только никогда не состоявших в браке, но и никогда не состоявших в сожительстве. В анализируемых странах доля одиноких минимальна, т.е. составляет менее $10 \%$ для всех рассматриваемых когорт, близких к завершению своей матримониальной биографии в Венгрии, Нидерландах, России, Франции, Австрии, Литве (таблица 4). Заметна тенденция снижения числа одиноких в Чехии, Франции, России (на фоне увеличения доли никогда не состоявших в браке к моменту опроса).

По доле тех, кто пережил развод, Россия схожа с такими странами, как Венгрия, Чехия, Франция (рисунки 9-11). В Германии и Нидерландах эта доля чуть меньше, и наблюдается тенденция к ее снижению. Она минимальна в Грузии, Болгарии, Италии, но и в этих странах существенно возрастает для молодых когорт. 
Таблица 4. Доля не имевших опыта брачно-партнерского союза к моменту опроса в общем числе респондентов когорты, \%

\begin{tabular}{|c|c|c|c|c|c|c|c|c|c|c|}
\hline \multicolumn{11}{|c|}{ Страны, где изменения наиболее заметны } \\
\hline \multirow[b]{2}{*}{$\begin{array}{l}\text { Годы } \\
\text { рождения }\end{array}$} & \multicolumn{2}{|c|}{ Австрия } & \multicolumn{2}{|c|}{ Нидерланды } & \multicolumn{2}{|c|}{ Германия } & \multicolumn{2}{|c|}{ Франция } & \multicolumn{2}{|c|}{ Чехия } \\
\hline & 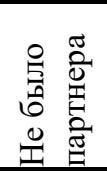 & 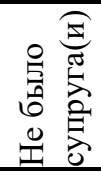 & 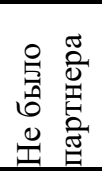 & 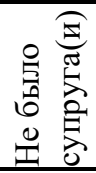 & 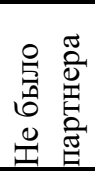 & 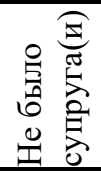 & 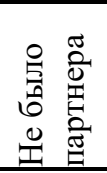 & 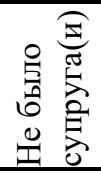 & 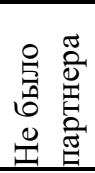 & 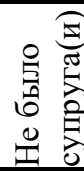 \\
\hline 1924-1929 & & & 7 & 10 & 32 & 34 & 16 & 20 & 17 & 17 \\
\hline 1930-1934 & & & 6 & 9 & 25 & 26 & 13 & 15 & 16 & 18 \\
\hline 1935-1939 & & & 5 & 6 & 13 & 16 & 10 & 12 & 11 & 13 \\
\hline 1940-1944 & & & 4 & 7 & 11 & 14 & 6 & 11 & 8 & 11 \\
\hline 1945-1949 & & & 5 & 11 & 7 & 10 & 7 & 15 & 7 & 12 \\
\hline 1950-1954 & & & 5 & 15 & 10 & 15 & 6 & 15 & 10 & 14 \\
\hline 1955-1959 & & & 5 & 18 & 11 & 17 & 7 & 21 & 10 & 16 \\
\hline 1960-1964 & 3 & 14 & 6 & 22 & 10 & 16 & 6 & 30 & 9 & 19 \\
\hline 1965-1969 & 4 & 20 & 6 & 27 & 12 & 25 & 5 & 31 & 9 & 20 \\
\hline 1970-1974 & 5 & 26 & 10 & 42 & 11 & 28 & 8 & 41 & 13 & 30 \\
\hline $1975-1979$ & 6 & 38 & 16 & 58 & 18 & 51 & 12 & 59 & 20 & 52 \\
\hline 1980-1984 & 13 & 65 & 39 & 87 & 46 & 76 & 22 & 84 & 42 & 85 \\
\hline 1985-1989 & 33 & 90 & 64 & 93 & 84 & 100 & 58 & 96 & 76 & 98 \\
\hline
\end{tabular}

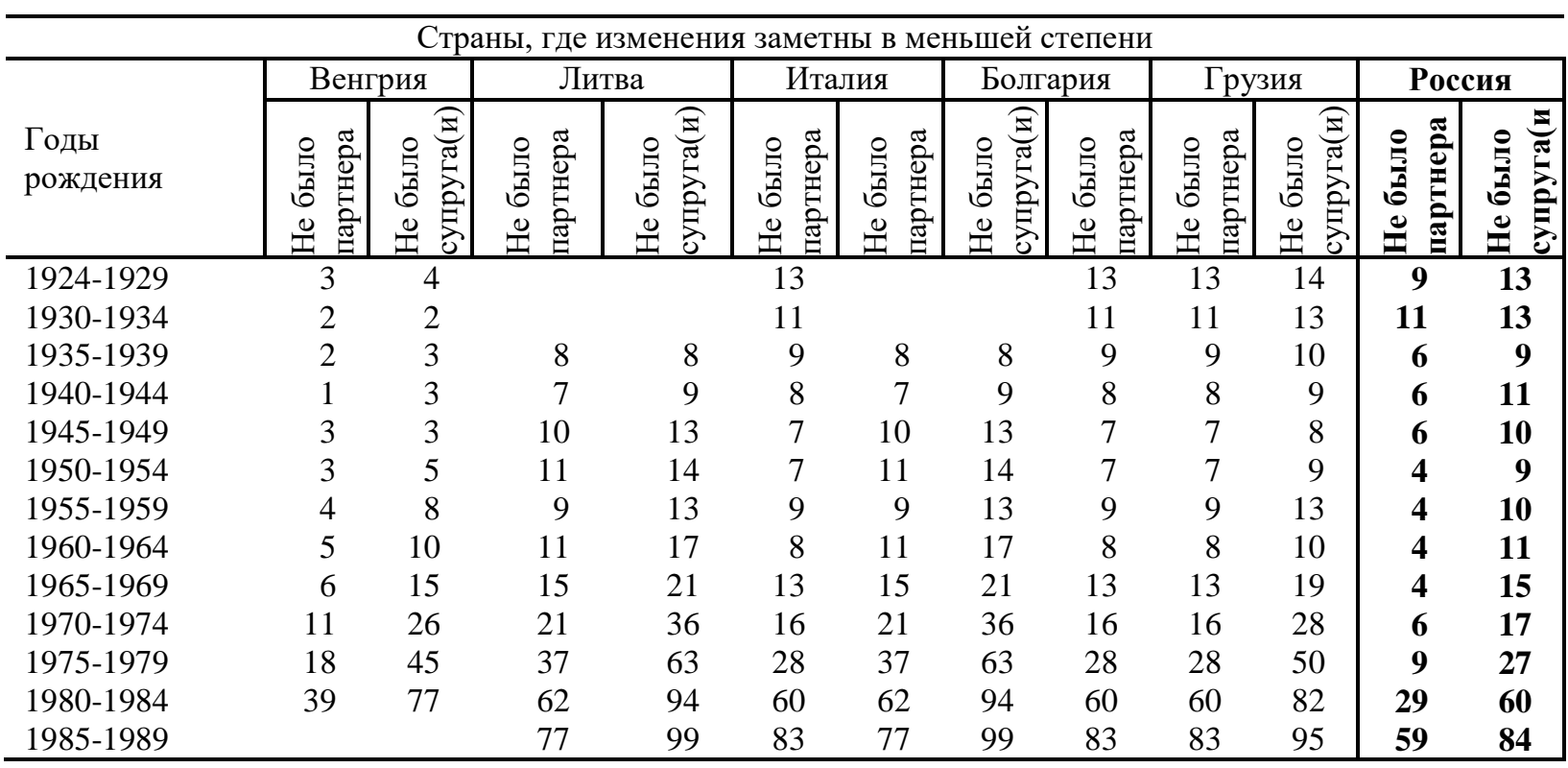

Источник: Составлено авторами по данным GGS (Волна 2). 


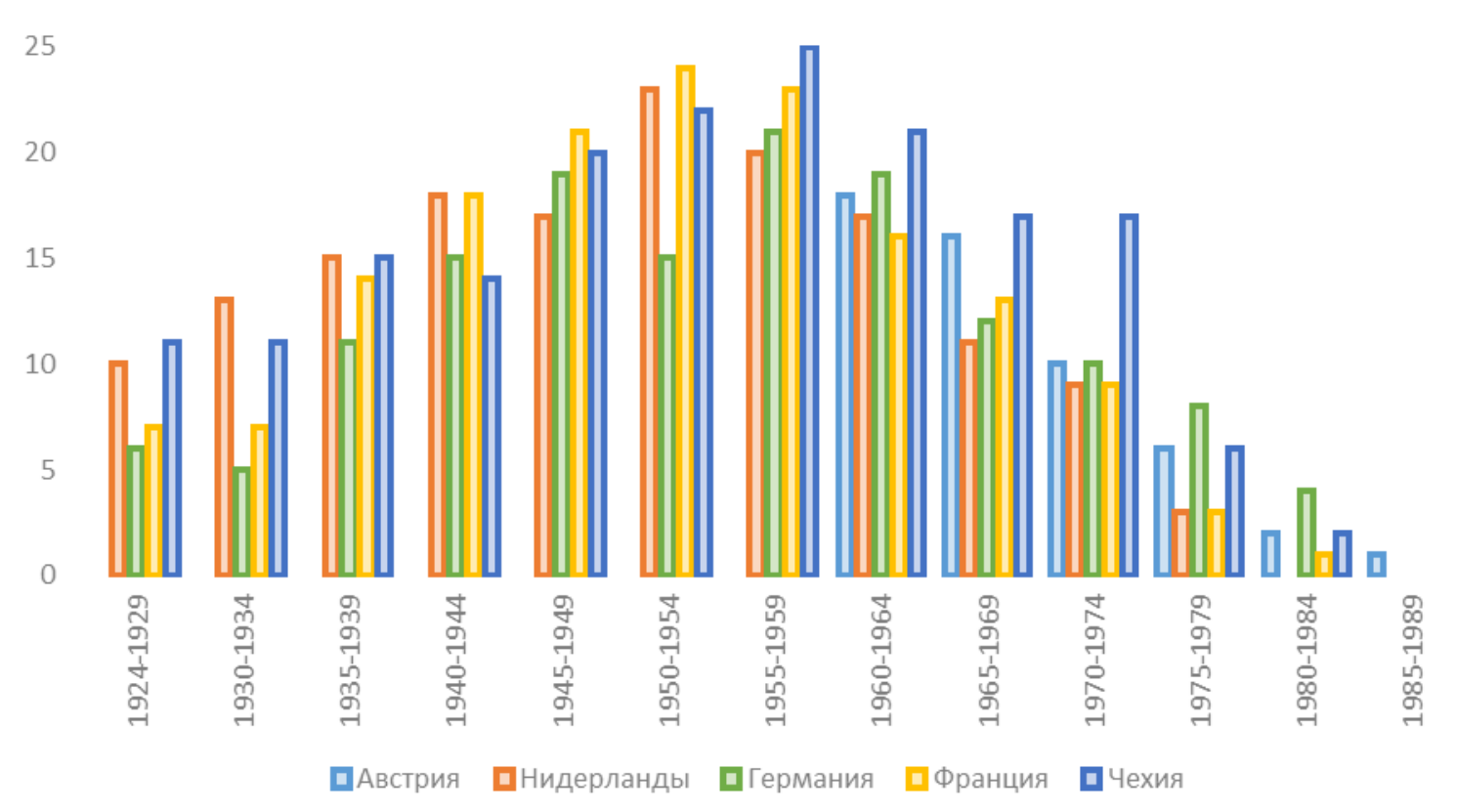

Рисунок 9. Доля имевших опыт развода к моменту опроса в общем числе респондентов когорты, когда-либо состоявших в первом браке, \%. Австрия, Нидерланды, Германия, Франция, Чехия

Источник: Составлено авторами по данным GGS (Волна 2).

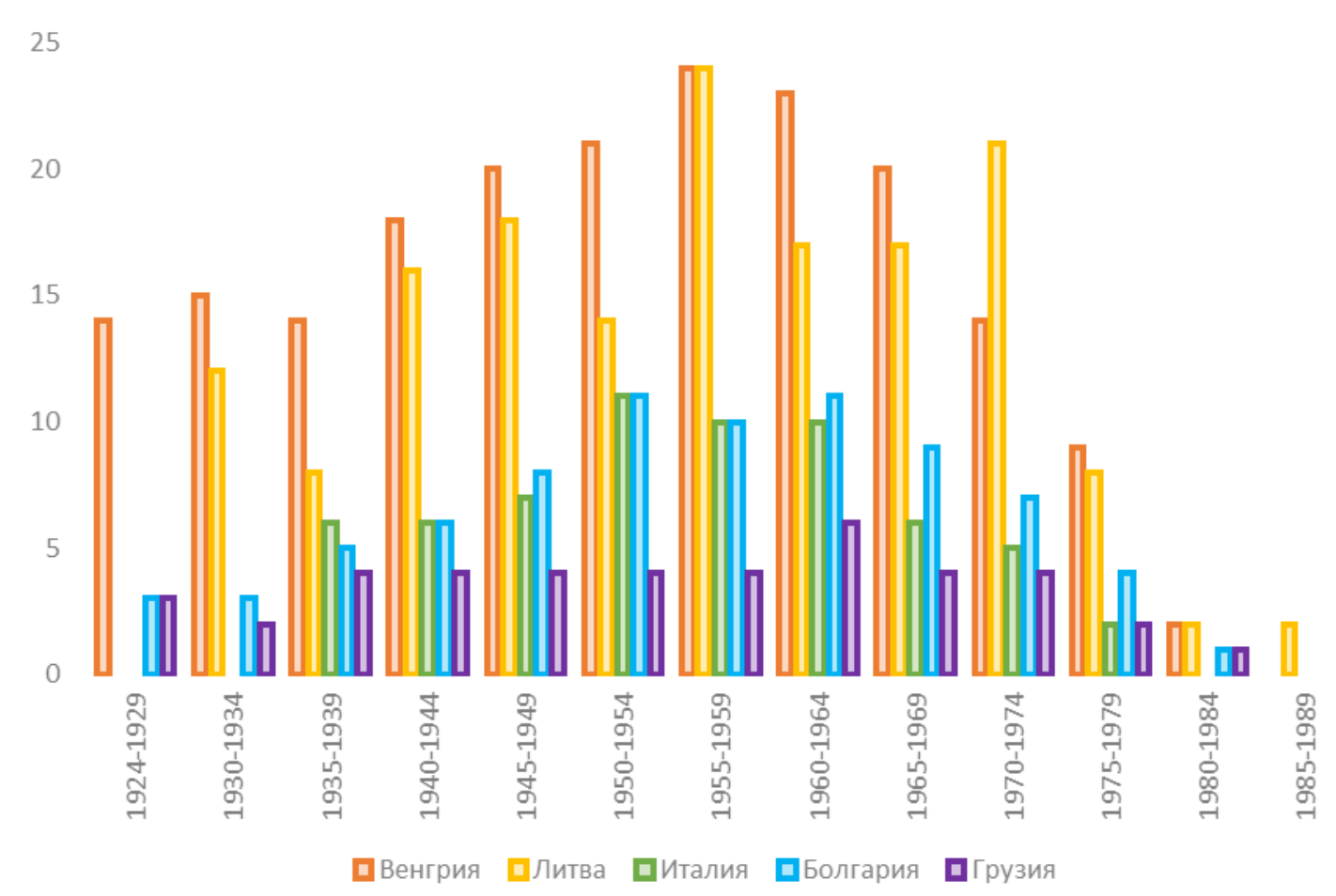

Рисунок 10. Доля имевших опыт развода к моменту опроса в общем числе респондентов когорты, когда-либо состоявших в первом браке, \%. Венгрия, Литва, Италия, Болгария, Грузия

Источник: Составлено авторами по данным GGS (Волна 2). 


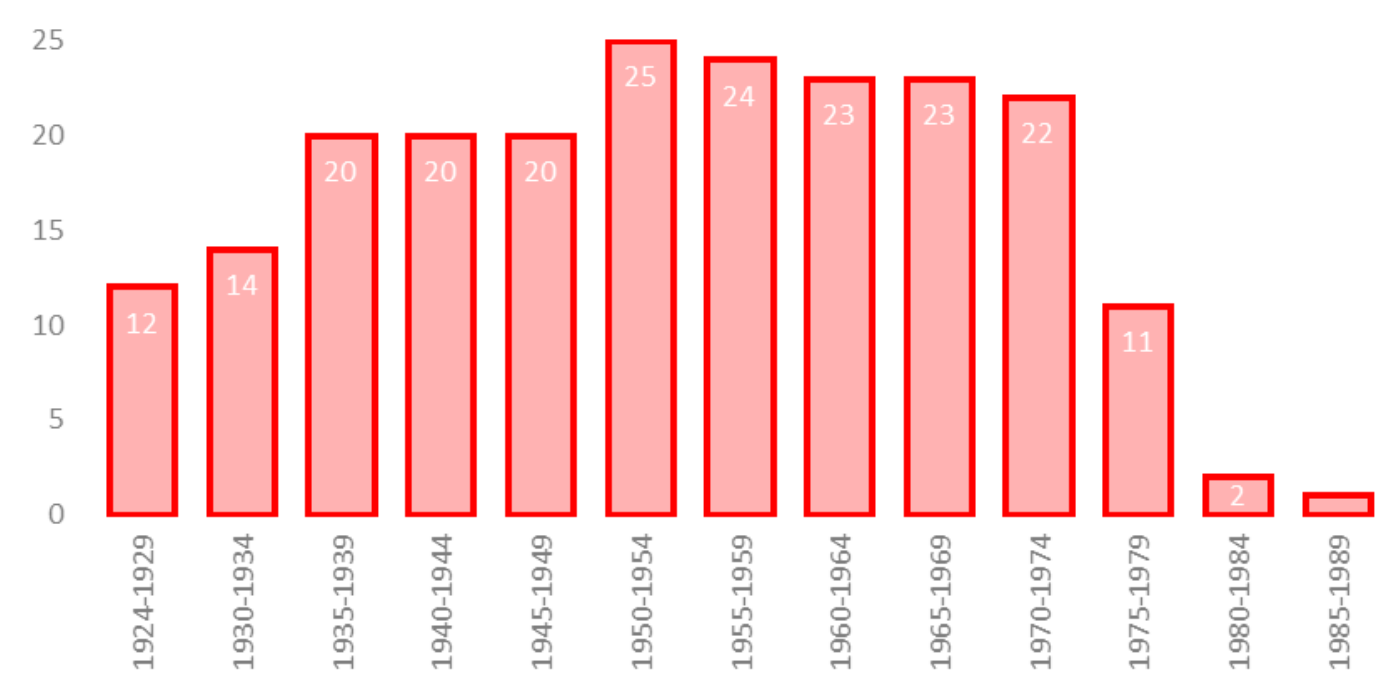

Рисунок 11. Доля имевших опыт развода к моменту опроса в общем числе респондентов когорты, когда-либо состоявших в первом браке, \%. Россия

Источник: Составлено авторами по данным $G G S$ (Волна 2).

В рассматриваемых странах повторный брак выглядит не очень частым явлением (рисунки 12-14). Доля тех, кто имеет опыт вступления во второй брак, в среднем по всем когортам колеблется от 0,8\% в Грузии до 9,8\% в России. Процент повторных браков также низок в Италии и Болгарии, а высок - в Венгрии и Чехии. В целом, по странам заметна тенденция к снижению доли людей, вступающих во второй брак, что может быть результатом как эффекта возраста (молодые когорты еще не успели пройти через это матримониальное событие), так и тем, что после неудачного опыта первого брака люди сегодня предпочитают сожительство.

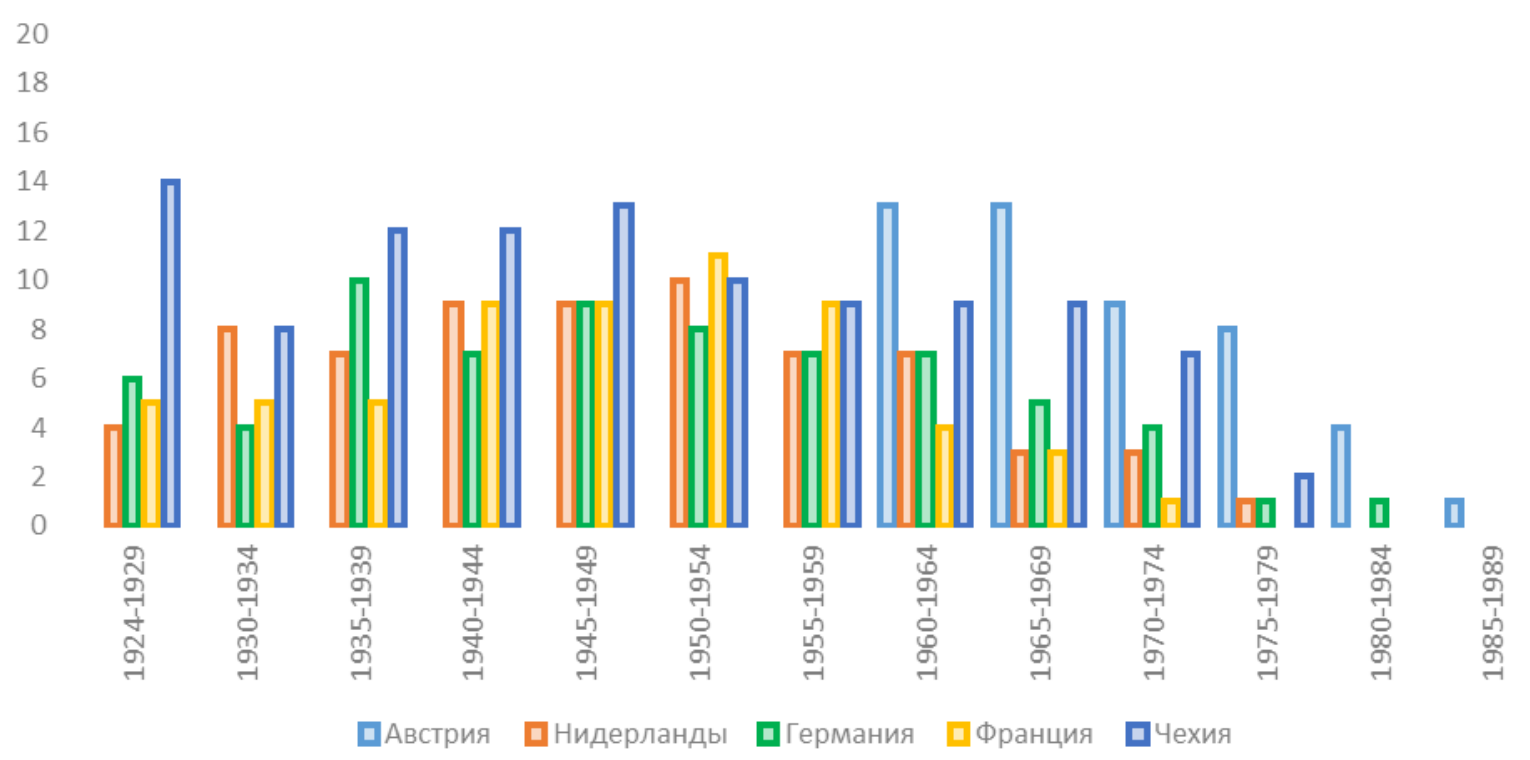

Рисунок 12. Доля имевших опыт второго брака к моменту опроса в общем числе респондентов когорты, \%. Австрия, Нидерланды, Германия, Франция, Чехия

Источник: Составлено авторами по данным GGS (Волна 2). 


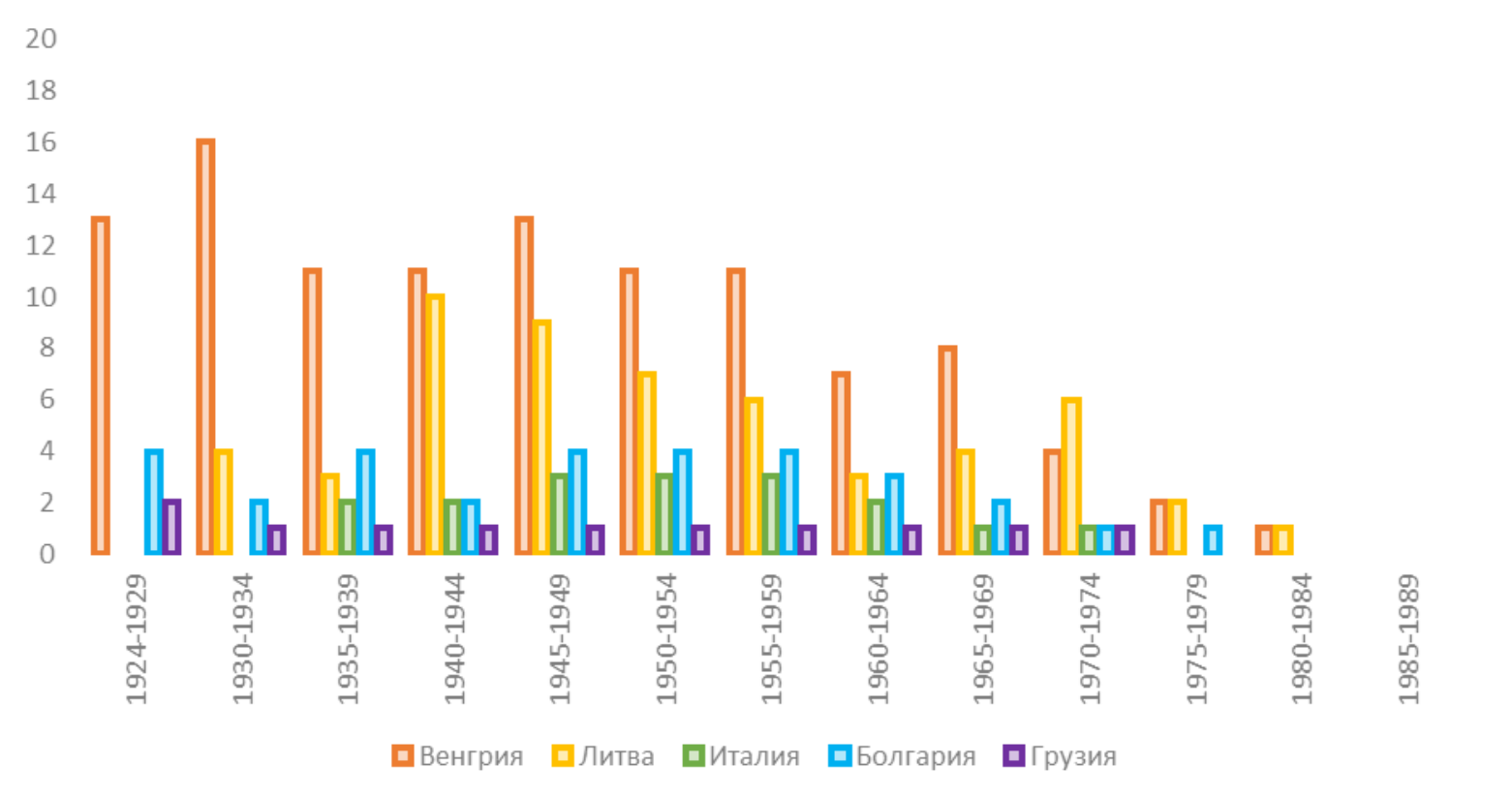

Рисунок 13. Доля имевших опыт второго брака к моменту опроса в общем числе респондентов когорты, \%. Венгрия, Литва, Италия, Болгария, Грузия

Источник: Составлено авторами по данньмм GGS (Волна 2).

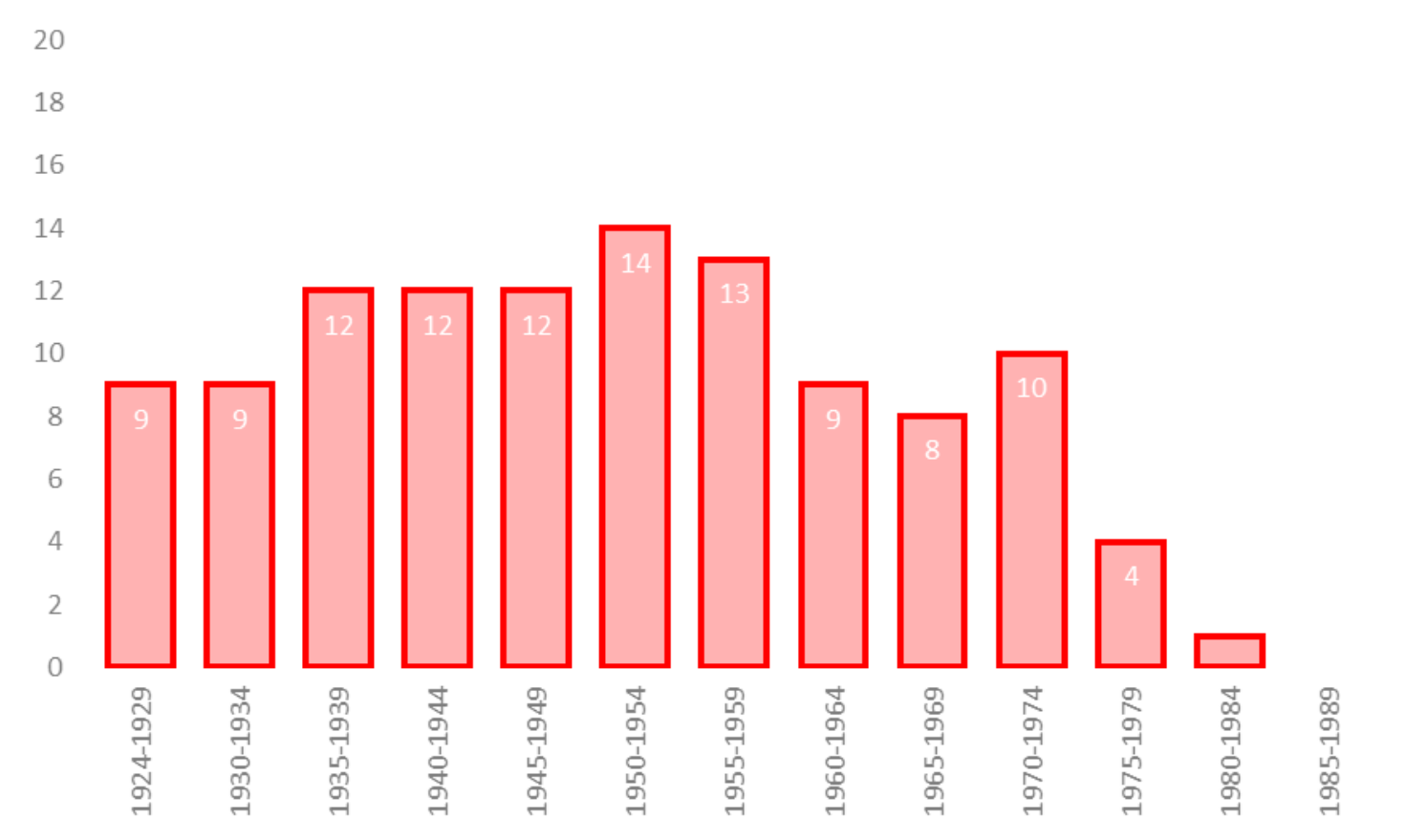

Рисунок 14. Доля имевших опыт второго брака к моменту опроса в общем числе респондентов когорты, \%. Россия

Источник: Составлено авторами по данным GGS (Волна 2).

В анализируемых странах наблюдаются тенденции, характерные для унифицирующихся социальных пространств индустриальных и постиндустриальных обществ, но отличающиеся скоростью изменений: увеличение числа партнеров в течение жизни, постепенное снижение доли людей, вступающих в брак, повышение доли условно 
одиноких, снижение числа вторых браков. Эти изменения заметнее в странах Северной (Литва), Западной (Германия, Франция, Нидерланды) и Центральной (Австрия, Чехия) Европы, которые, в основном, отличаются западноевропейским типом брачности, преобладанием ценностей «рациональность-самовыражение» и консервативным режимом социальной политики. Изменения менее заметны в Венгрии, Болгарии и Грузии (странах с преимущественно восточноевропейским типом брачности, преобладанием ценностей «рациональность-выживание» и посткоммунистическим или формирующимся режимом семейной политики). Россия занимает промежуточную позицию, лидируя только по такому показателю, как средняя доля тех, кто прошел через развод к моменту опроса.

\section{Выбор первого матримониального союза в России: детерминанты мезо- и макроуровней}

В ходе построения дерева классификации респондентов РиДМиЖ для стартов их брачнопартнерских биографий было выявлено, что ключевой переменной, детерминирующей этот выбор, является принадлежность к поколению. Ниже представлены результаты, полученные на контрольной выборке. На первом шаге респонденты были разделены на три группы на основании принадлежности к определенному поколению:

1. родившиеся с 1935 по 1964 гг.;

2. родившиеся с 1965 по 1974 гг.;

3. родившиеся с 1975 по 1984 гг.

Такое деление не случайно: оно позволяет судить о деинституционализации жизненных путей россиян после распада Советского Союза. Представители поколений 1935-1964 годов рождения предпочитают браки (76,9\%), причем максимальна их доля среди тех, кто вступает в союз в возрасте 17-26 лет. Более склонны к вступлению в сожительство жители городов, если они вступают в союз до 17 лет и взрослые люди (старше 26 лет), отделившиеся от родительского дома до начала матримониальной биографии (Приложение 1).

Среди представителей поколения 1965-1974 годов рождения также преобладают выбирающие браки в качестве первых союзов, однако перевес уже не такой большой, как в случае предшествующих поколений (60\% выбирают браки, 40\% - сожительства). Выбор союза в этом поколении также определяется возрастом вступления в союз: начинают матримониальную биографию с незарегистрированного союза либо молодые (до 17 лет), либо уже взрослые люди (после 26 лет). Вступающие в союз в 17-26 лет предпочитают браки (Приложение 1).

Среди представителей поколения 1975-1984 годов рождения преобладают начинающие брачно-партнерские траектории с сожительства (44\% выбирают браки, 56\% сожительства). Зарегистрированный союз выбирают респонденты, выросшие с обоими родными родителями, вступившие в союз после наступления зачатия. Сожительство предпочитают те, кто пережил расставание родителей, вступившие в союз не по причине наступления зачатия и начавшие работать до 20 лет (Приложение 1). 
Бинарная логистическая регрессия поможет глубже взглянуть на трансформацию матримониального поведения в России.

Нами было построено семь регрессионных моделей, где зависимой переменной выступал первый союз (1 - первое сожительство, 0 - первый брак). Первая модель общая, она была построена для выборки респондентов, вступивших в первый союз. Шесть других моделей были построены отдельно для мужчин и женщин из уже упомянутых выше поколений 1934-65, 1965-74 и 1975-84 годов рождений (таблица 5).

Таблица 5. Бинарная логистическая регрессия: факторы выбора первого союза

\begin{tabular}{|c|c|c|c|c|c|c|c|}
\hline \multirow{2}{*}{ Детерминанты } & \multirow{2}{*}{ Общая } & \multicolumn{2}{|c|}{ 1935-1964 } & \multicolumn{2}{|c|}{ 1965-1974 } & \multicolumn{2}{|c|}{ 1975-1984 } \\
\hline & & Муж & Жен & Муж & Жен & Муж & Жен \\
\hline $\begin{array}{l}\text { Тип населенного пункта реф: } \\
\text { село }\end{array}$ & $1,375 * * *$ & $1,803 * * *$ & $1,189 *$ & $1,861 * *$ & 1,267 & 1,251 & $1,609 * *$ \\
\hline $\begin{array}{l}\text { Уровень образования реф: } \\
\text { высшее }\end{array}$ & $1 * * *$ & 1 & 1 & $1 * *$ & 1 & $1 * *$ & $1 * *$ \\
\hline Общее & $1,677 * * *$ & 1,467 & 1,205 & $2,160 * *$ & $1,861 * *$ & $4,053 * *$ & $2,523 * *$ \\
\hline Профессиональное & $1,343 * * *$ & $1,614 * *$ & 0,956 & $2,403 * *$ & 1,234 & $2,722 * *$ & $1,645^{*}$ \\
\hline Возраст вступления в союз & $1,026 * *$ & 0,99 & 1,023 & $1,131 * * *$ & 1,009 & 1,022 & 1,01 \\
\hline $\begin{array}{l}\text { Предшествовало ли зачатие } \\
\text { союзу реф: да }\end{array}$ & $1,719 * * *$ & $1,455 * *$ & $1,569 * *$ & $1,685^{*}$ & $1,586 * *$ & $3,895^{* *}$ & $2,370 * *$ \\
\hline $\begin{array}{l}\text { Было ли отделение до } \\
\text { вступления в союз реф: да }\end{array}$ & $0,708 * * *$ & $0,745^{*}$ & $0,782 * *$ & 0,778 & $0,693 * *$ & 0,578 & $0,402 * * *$ \\
\hline $\begin{array}{l}\text { Расходились ли родители реф: } \\
\text { да }\end{array}$ & $0,640 * * *$ & 1,063 & $0,616^{* * *}$ & $0,434 * *$ & $0,657 * *$ & $0,248 * *$ & 0,735 \\
\hline $\begin{array}{l}\text { Возраст начала трудовой } \\
\text { карьеры }\end{array}$ & $0,960 * * *$ & 1,003 & $0,965 * *$ & $0,895 * *$ & $0,945^{*}$ & 0,94 & $0,907 * *$ \\
\hline Пол реф: женский & 0,904 & & & & & & \\
\hline Реф: 1975-1984 & $1 * * *$ & & & & & & \\
\hline $1935-1944$ & $0,159 * * *$ & & & & & & \\
\hline $1945-1954$ & $0,213 * * *$ & & & & & & \\
\hline $1955-1964$ & $0,223 * * *$ & & & & & & \\
\hline $1965-1974$ & $0,490 * * *$ & & & & & & \\
\hline Константа & 1,305 & $0,136 * *$ & $0,382 *$ & 0,15 & 1,478 & 1,811 & 4,098 \\
\hline
\end{tabular}

Источник: Рассчитано авторами по данным РиДМиЖ (2004, 2007, 2011)

Примечания: *** $p<0,1, * * p<0,05, * p<0,001$; реф. - референтная категория

При прочих равных условиях отношение шансов вступления в сожительство к шансам вступления в брак повышают: проживание в городе, а не в сельской местности (в 1,4 раза), наличие общего или профессионального образования (в 1,7 и 1,3 раза по сравнению с высшим образованием), дополнительный год возраста вступления в союз (на $1,03)$, отсутствие зачатия, предшествующего союзу (в 1,7 раза); снижают: проживание с родителями до вступления в союз (в 0,7 раза), благополучность родительской семьи (в 0,6 раза), каждый дополнительный год откладывания начала трудовой карьеры (на 0,96$)$, принадлежность к поколению социализировавшихся до отказа от социализма (в среднем в 0,3 раза).

Частные модели с разделением по полу и возрасту детализируют различия в начале матримониальных биографий россиян разных поколений. Для самого молодого поколения максимален эффект от наступления зачатия на увеличение шансов выбора брака, а не сожительства. 
Отделение от родителей до вступления в союз является значимой детерминантой выбора сожительства, а не брака только для женщин, и это повторяет результат испанских и итальянских исследований, показавших, что к выбору брака в качестве первого союза более склонны девушки, не покинувшие родительский дом до начала совместного проживания с партнером [Pereiro, Pace, Didonna 2014]). Это можно истолковать таким образом, что более независимые женщины предпочитают не обременять себя зарегистрированным союзом. Об этом же косвенно свидетельствует то, что увеличение возраста начала трудовой карьеры на 1 год уменьшает риск вступить в сожительство в среднем на 0,94, но значим этот показатель для мужчин, родившихся только в 1964-1975 годах и женщин всех поколений.

Наличие общего или профессионального образования увеличивает риск выбора сожительства, а не брака в качестве первого союза для мужчин и женщин всех поколений, и эта тенденция пока устойчива в России, что также перекликается с результатами исследования М. Миллс, показавшей, что в России сожительство выбирают не самые благополучные слои населения. Такой вывод роднит нашу страну с США, где распространение сожительств можно объяснить теорией Паттерна неблагоприятных условий, в то время как получившие высшее образование выбирают браки [Mills et al 2013].

Тип населенного пункта в меньшей степени определяет выбор союза для молодых поколений, чем для поколений советских (становится все менее значим с точки зрения статистики), хотя для женщин поколения 1975-1984 годов рождения проживание в городе увеличивает риск вступления в сожительство в 1,6 раза.

\section{Выводы}

В рамках данного исследования было выявлено, что в России происходят изменения, характерные для унифицирующихся социальных пространств индустриальных и постиндустриальных обществ: увеличение числа партнеров в течение жизни, постепенное снижение доли людей, вступающих в брак, повышение доли условно одиноких, снижение числа вторых браков. На макроуровне изменения в матримониальном поведении могут быть объяснены исторически сформировавшимся в стране типом брачности, профилем ценностей граждан, режимом семейной политики государства. Чтобы изучить роль факторов макроуровня, мы провели исследование на гармонизированных данных второй волны международного обследования «Поколение и Гендер», доступных для 10 европейских стран, включая Россию. Результаты проведенного анализа показали, что изменения в брачно-партнерском поведении заметнее в странах Западной и Центральной Европы, которые, в основном, отличаются западноевропейским типом брачности, преобладанием ценностей «рациональность-самовыражение» и консервативным режимом социальной политики. Изменения менее заметны в странах преимущественно с восточноевропейским типом брачности, преобладанием ценностей «рациональностьвыживание» и посткоммунистическим или формирующимся режимом социальной политики. 
Влияние факторов мезо- и микроуровня на матримониальное поведение было изучено на панели трех волн того же обследования «Поколение и Гендер», но только для российской части обследования. На мезоуровне выбор россиянами, как и другими европейцами, детерминанты поведения которых были рассмотрены на примере зарубежных исследований, сожительства или брака в качестве первого брачнопартнерского союза определяет тип населенного пункта, в котором проживают респонденты. Возраст вступления в союз, предшествие зачатия вступлению в союз, матримониальный опыт родителей, обстоятельства покидания родительского дома и выхода на рынок труда, уровень образования выступают факторами выбора первого матримониального союза на микроуровне. При прочих равных условиях, риск вступить в сожительство увеличивают наличие общего или профессионального образования, проживание в городе, а риск вступить в брак увеличивают зачатие, предшествующее союзу, проживание с родителями до вступления в союз, благополучность родительской семьи, каждый дополнительный год откладывания начала трудовой карьеры для женщин. В целом, Россия вписывается в тенденции трансформации матримониального поведения европейских стран.

\section{ЛИТЕРАТУРА}

Вебер М. (1990). Избранные произведения: Пер. с нем. / Сост., общ. ред. и послесл. Ю. Н. Давыдова; Предисл. П. П. Гайденко. М.: Прогресс. 808 с.

Вишневский А.Г. (1982). Воспроизводство населения и общество. История, современность, взгляд в будущее. М.: Финансы и статистика. 287 с.

Вишневский А. Г. (2009). Незавершенная демографическая модернизация в России. SPERO. 10: 55-82.

Демографическая модернизация России, 1900-2000. (2006) / Под ред. А.Г. Вишневского. М.: Новое издательство. 608 с.

Елизаров В.В. (2013). Семейная политика: прошлое, настоящее, будущее. Стратегия демографического развития России: рождаемость и семейная политика // Материалы Всероссийской научно-практической конференции 19-20 июня 2013 г. М.: Эконинформ.: 10-28.

Захаров С.В., О. Г. Исупова (2014). Брачность и брачное состояние // В кн.: Население России 2012: двадцатый ежегодный демографический доклад / Отв. ред.: А. Г. Вишневский. М.: Издательский дом НИУ ВШЭ: 57-98.

Исупова О.Г. (2015). Российские консенсуальные союзы начала XXI века (по данным международного сравнительного исследования) // Мониторинг общественного мнения: экономические и социальные перемены. № 2 (126): 153-165.

Левада Ю. (2005). Поколения XX века: возможности исследования // Отцы и дети: Поколенческий анализ современной России / Сост. Ю. Левада, Т. Шанин. М.: 39-60.

Медведева С.В., А.О. Тындик (2015). В какой мере реализуются намерения жить вместе? // Демоскоп Weekly. № 625 - 626. URL: http://www.demoscope.ru/weekly/2015/0625/analit04.php (дата обращения 05.11.2017).

Avdeev A., A. Monnier (2000). Marriage in Russia: A complex phenomenon poorly understood // Population: An English Selection. V. 12: 7-49. 
Balbo N., F.C. Billari, M. Mills (2013). Fertility in advanced societies: a review of research // European Journal of Population. 29 (1): 1-38.

Bukodi E. (2012). The relationship between work history and partnership formation in cohorts of British men born in 1958 and 1970 // Population Studies. 66 (2): 123-145.

Butler. J. (2012). Precarious life, vulnerability, and the ethics of cohabitation // The Journal of Speculative Philosophy. 26 (2). Special issue with the society for phenomenology and existential philosophy: 134-151.

Esping-Andersen G. (1990). The three worlds of welfare capitalism. Princeton University Press: $260 \mathrm{p}$.

Esping-Andersen G. (2009). The incomplete revolution: adapting to women's new roles. Cambridge: Polity Press: 214 p.

Gault-Sherman M., S. Draper (2012). What will the neighbors think? The effect of moral communities on cohabitation // Review of Religious Research. 54 (1): 45-67.

Gerber T.P., D. Berman (2010). Entry to marriage and cohabitation in Russia, 1985-2000: Trends, correlates, and implications for the second demographic transition // European Journal of Population Review. 26: 3-31.

Hajnal, J. (1965). European marriage patterns in perspective / D. V. Glass, D. E. C. Eversley, ed. Population in history: essays in historical demography. London, Edward Arnold: 101-143.

Hantaris L. (2004). Family policy matters: responding to family change in Europe. Bristol: The Policy Press: 256 p.

Inglehart R., C. Welzel (2005). Modernization, cultural change, and democracy: the human development sequence. New York. Cambridge University Press: 340 p.

Inglehart R., C. Welzel (2010). Changing mass priorities: the link between modernization and democracy // Perspectives on Politics. 8 (2): 551-567.

Kaa, D.J. van de, R. Lesthaeghe (1986). Two demographic transitions? // Population: Growth and Decline: $9-24$.

Lesthaeghe R. (1995). The second demographic transition in Western countries: an interpretation // Gender and Family Change in Industrialized Countries. Oxford: Clarendon Press: 17-62.

Mills M. (2004). Stability and change: the structuration of partnership histories in Canada, the Netherlands, and the Russian Federation // European Journal of Population. 20: 141-175.

Mills M., H. Blossfeld (2013). The second demographic transition meets globalization: a comprehensive theory to understand changes in family formation in an era of rising uncertainty // Life Course Research and Social Policies. 1: 9-33.

Mills M., L. Lesnard, G. Potarca (2013). Family formation trajectories in Romania, the Russian federation and France: towards the second demographic transition? // European Journal of Population. 29: 69-101.

Pereiro T., P. Pace, M. Didonna (2014). Entering first union: the choice between cohabitation and marriage among women in Italy and Spain // Journal of Population Research. 31: 51-70.

Perelli-Harris B., M. Lyons-Amos (2015). Changes in partnership patterns across the life course: An examination of 14 countries in Europe and the United States // Demographic Research. 33: $145-178$.

Perelli-Harris B., O.G. Isupova, M. Mynarska, A. Berrington, A. Evans, R. Keizer, A. Klaerner, Berghammer C., T. Lappeguard, D. Vigholi (2014). Towards a new understanding of 
cohabitation: Insights from focus group research across Europe and Australia // Demographic Research. 31 (34): 1043-1078.

Puur A., S. Zakharov, L. Rahnu, A. Maslauskaite, V. Stankuniene (2012). Transformation of partnership formation in Eastern Europe: The legacy of the past demographic divide // Journal of Comparative Family Studies. 43(3): 389-417. 


\title{
MATRIMONIAL BEHAVIOR OF RUSSIANS IN A EUROPEAN CONTEXT
}

\author{
ALENA ARTAMONOVA, EKATERINA MITROFANOVA
}

\begin{abstract}
The first objective of this study was to provide an overview that briefly describes how modern research explains changes in matrimonial behavior in time and space (heterogeneity between European countries and within Russia). The second objective was to identify the main determinants of the choice of the first matrimonial union that function at macro-, meso-, and micro-levels. The third and main objective was to find an answer to the question of how changes in the matrimonial behavior of Russians are correlated with trends observed in other European countries. For this purpose, the second wave data of the international survey "Generation and Gender" and panel data of the Russian part of the same survey were employed.
\end{abstract}

The analysis demonstrated that in Russia, changes typical for the unified social spaces of industrial and postindustrial societies are taking place: an increase in the number of partners over a lifetime, a gradual decrease in the proportion of people getting married, an increase in the share of single people, and a decrease in the number of second marriages. Intercountry differences in matrimonial behavior are explained by a country's historically formed type of marriage, the values profile of the population, and the family policy regime (macro-level). In Russia, as well as in other countries, the choice of first matrimonial event type is determined by the type of settlement (meso-level), age at the first union, conception preceding the union, the matrimonial experience of parents, the circumstances of leaving the parental home and entering the job market, and the level of education (micro-level).

Key words: first matrimonial union, marriage, cohabitation, life course, second demographic transition.

\begin{abstract}
Alena V. Artamonova (aaaav@iscte-iul.pt), an Erasmus Mundus Family Joint Master student (ISCTE UNIVERSITY INSTITUTE OF LISBON), PORTUGAL (COORD.); UNIVERSITY OF GOTHENBURG, SWEDEN; UNIVERSITY OF STAVANGER, NORWAY; MAKERERE UNIVERSITY, UGANDA.
\end{abstract}

EkATERINa S. Mitrofanova (emitrofanova@hse.ru), NATIONAL RESEARCH University Higher School of ECONOMICS, RUSSIA.

THE ARTICLE WAS PREPARED WITHIN THE FRAMEWORK OF THE ACADEMIC FUND PROGRAM AT THE NATIONAL RESEARCH UNIVERSITY HIGHER SCHOOL OF ECONOMICS (HSE) IN 2016 (GRANT № 16-05-OO11 “DEVELOPMENT AND TESTING OF DEMOGRAPHIC SEQUENCE ANALYSIS AND MINING TECHNIQUES”) AND SUPPORTED WITHIN THE FRAMEWORK OF A SUBSIDY GRANTED TO THE HSE BY THE GOVERNMENT OF THE RUSSIAN FEDERATION FOR THE IMPLEMENTATION OF THE GLOBAL COMPETITIVENESS PROGRAM.

DATE RECEIVED: DECEMBER 2017.

\section{REFERENCES}

Avdeev A., A. Monnier (2000). Marriage in Russia: A complex phenomenon poorly understood // Population: An English Selection. 12: 7-49.

Balbo N., F.C. Billari, M. Mills (2013). Fertility in advanced societies: a review of research // European Journal of Population. 29 (1): 1-38.

Bukodi E. (2012). The relationship between work history and partnership formation in cohorts of British men born in 1958 and 1970 // Population Studies. 66 (2): 123-145.

Butler. J. (2012). Precarious life, vulnerability, and the ethics of cohabitation // The Journal of Speculative Philosophy. 26 (2). Special issue with the society for phenomenology and existential philosophy: 134-151. 
Demograficheskaja modernizacija Rossii, 1900-2000. [Demographic modernization of Russia, 1900-2000]. (2006) / A.G. Vishnevsky, ed. M.: Novoe izdatel'stvo. 608 p.

Esping-Andersen G. (1990). The three worlds of welfare capitalism. Princeton University Press: $260 \mathrm{p}$.

Esping-Andersen G. (2009). The incomplete revolution: adapting to women's new roles. Cambridge: Polity Press: 214 p.

Gault-Sherman M., S. Draper (2012). What will the neighbors think? The effect of moral communities on cohabitation // Review of Religious Research. 54 (1): 45-67.

Gerber T.P., D. Berman (2010). Entry to marriage and cohabitation in Russia, 1985-2000: Trends, correlates, and implications for the second demographic transition // European Journal of Population Review. 26: 3-31.

Hajnal, J. (1965). European marriage patterns in perspective / D. V. Glass, D. E. C. Eversley, ed. Population in history: essays in historical demography. London, Edward Arnold: 101-143.

Hantaris L. (2004). Family policy matters: responding to family change in Europe. Bristol: The Policy Press: $256 \mathrm{p}$.

Inglehart R., C. Welzel (2005). Modernization, cultural change, and democracy: the human development sequence. New York. Cambridge University Press: 340 p.

Inglehart R., C. Welzel (2010). Changing mass priorities: the link between modernization and democracy // Perspectives on Politics. 8 (2): 551-567.

Isupova O.G. (2015). Rossijskie konsensual'nye sojuzy nachala XXI veka (po dannym mezhdunarodnogo sravnitel'nogo issledovanija) [The Russian consensual unions of the beginning of the 21 st century (according to the international comparative research)] // Monitoring obshhestvennogo mnenija: jekonomicheskie i social'nye peremeny [The Monitoring of Public Opinion: Economic and Social Changes Journal]. 2 (126): 153-165.

Kaa, D.J. van de, R. Lesthaeghe (1986). Two demographic transitions? // Population: Growth and Decline: 9-24.

Lesthaeghe R. (1995). The second demographic transition in Western countries: an interpretation // Gender and Family Change in Industrialized Countries. Oxford: Clarendon Press: 17-62.

Levada Yu. (2005). Pokolenija XX veka: vozmozhnosti issledovanija [Generations of the XX century: possibilities of a research] // Otcy i deti: Pokolencheskij analiz sovremennoj Rossii [Fathers and children: Generational analysis of modern Russia] / Yu. Levada, T. Shanin, eds.. M.: 39-60.

Medvedeva S.V., A.O. Tyndik (2015). V kakoj mere realizujutsja namerenija zhit' vmeste? [How people realize their intensions to live together?] // Demoscope Weekly. 625 - 626. URL: http://www.demoscope.ru/weekly/2015/0625/analit04.php (accessed 05.11.2017).

Mills M. (2004). Stability and change: the structuration of partnership histories in Canada, the Netherlands, and the Russian Federation // European Journal of Population. 20: 141-175.

Mills M., H. Blossfeld (2013). The second demographic transition meets globalization: a comprehensive theory to understand changes in family formation in an era of rising uncertainty // Life Course Research and Social Policies. 1: 9-33.

Mills M., L. Lesnard, G. Potarca (2013). Family formation trajectories in Romania, the Russian federation and France: towards the second demographic transition? // European Journal of Population. 29: 69-101. 
Pereiro T., P. Pace, M. Didonna (2014). Entering first union: the choice between cohabitation and marriage among women in Italy and Spain // Journal of Population Research. 31: 51-70.

Perelli-Harris B., M. Lyons-Amos (2015). Changes in partnership patterns across the life course: An examination of 14 countries in Europe and the United States // Demographic Research. 33: $145-178$.

Perelli-Harris B., O.G. Isupova, M. Mynarska, A. Berrington, A. Evans, R. Keizer, A. Klaerner, Berghammer C., T. Lappeguard, D. Vigholi (2014). Towards a new understanding of cohabitation: Insights from focus group research across Europe and Australia // Demographic Research. 31 (34): 1043-1078.

Puur A., S. Zakharov, L. Rahnu, A. Maslauskaite, V. Stankuniene (2012). Transformation of partnership formation in Eastern Europe: The legacy of the past demographic divide // Journal of Comparative Family Studies. 43(3): 389-417.

Vishnevsky A.G. (1982). Vosproizvodstvo naselenija i obshhestvo. Istorija, sovremennost', vzgljad v budushhee [Reproduction of the population and society. History, present, future]. M.: Finansy i statistika [Finance and statistics]. 287 p.

Vishnevsky A.G. (2009). Nezavershennaja demograficheskaja modernizacija v Rossii [Incomplete demographic modernization in Russia]. SPERO. 10: 55-82.

Weber M. (1990). Izbrannye proizvedenija [Selected Works]: Translated from German / Yu.N. Davydova, ed. M.: Progress. 808 p.

Yelizarov V.V. (2013). Semejnaja politika: proshloe, nastojashhee, budushhee. Strategija demograficheskogo razvitija Rossii: rozhdaemost' i semejnaja politika [Family policy: past, present, future. Strategy of demographic development of Russia: fertility and family policy] // Materialy Vserossijskoj nauchno-prakticheskoj konferencii 19-20 ijunja 2013. [Materials of the All-Russian scientific and practical conference on June 19-20, 2013]. M.: Ekoninform: 10-28.

Zakharov S.V., O.G. Isupova (2014). Brachnost' i brachnoe sostojanie [Naptuality and marital state] // In: Naselenie Rossii 2012: dvadcatyj ezhegodnyj demograficheskij doklad [Population of Russia 2012: twentieth annual demographic report] / Ed.: A.G. Vishnevsky. M.: Izdatel'skij dom NIU VShJe: 57-98. 


\section{Приложение 1. Классификация выбирающих браки и сожительства в качестве первых союзов (контрольная выборка)}

\begin{tabular}{|l|c|c|}
\hline \multicolumn{3}{|c|}{ Первый сою3 } \\
\hline & $\mathbf{\%}$ & $\mathbf{n}$ \\
\hline Сожительство & $31,1 \%$ & 587 \\
\hline Брак & $68,9 \%$ & 1257 \\
\hline Всего & $100 \%$ & 1824 \\
\hline
\end{tabular}

\begin{tabular}{|c|c|c|c|c|c|c|c|c|c|c|c|c|c|c|c|c|c|}
\hline \multicolumn{18}{|c|}{ Поколения, Скорр. Р-значение $=0,000$, Хи-квадрат=155,4, ст.св. $=2$} \\
\hline \multicolumn{3}{|c|}{$1935-1964$} & & & & & & & \multicolumn{3}{|c|}{1965 - 1974} & & & & & & \\
\hline Сожительство & $23,1 \%$ & 275 & & & & & & & Сожительство & $40,4 \%$ & 164 & & & & & & \\
\hline Брак & $76,9 \%$ & 913 & & & & & & & Брак & $59,6 \%$ & 242 & & & & & & \\
\hline Bcero & $65,1 \%$ & 1188 & & & & & & & Bcero & $22,3 \%$ & 406 & & & & & & \\
\hline \multicolumn{9}{|c|}{ Возраст вступления в первый союз, $\mathrm{P}=0,000$, Хи-кв=59,0, ст.св. $=2$} & \multicolumn{9}{|c|}{ Возраст вступления в первый союз, $\mathrm{P}=0,000$, Хи-кв $=32,0$, ст.св. $=2$} \\
\hline \multicolumn{3}{|c|}{$<=17$} & \multicolumn{3}{|c|}{$(17 ; 26]$} & \multicolumn{3}{|c|}{$>26$} & \multicolumn{3}{|c|}{$<=17$} & \multicolumn{3}{|c|}{$(17 ; 26]$} & \multicolumn{3}{|c|}{$>26$} \\
\hline Сожительство & $39,4 \%$ & 26 & Сожительство & $20,9 \%$ & 204 & Сожительство & $31,0 \%$ & 45 & Сожительство & $63,2 \%$ & 36 & Сожительство & $33,5 \%$ & 107 & Сожительство & $70,0 \%$ & 21 \\
\hline Брак & $60,6 \%$ & 40 & Брак & $79,1 \%$ & 773 & Брак & $69,0 \%$ & 100 & Брак & $36,8 \%$ & 21 & Брак & $66,5 \%$ & 212 & Брак & $30,0 \%$ & 9 \\
\hline Bcero & $3,6 \%$ & 66 & Bcero & $53,6 \%$ & 977 & Bcero & $7,9 \%$ & 145 & Bcero & $3,1 \%$ & 57 & Bcero & $17,5 \%$ & 319 & Bcero & $1,6 \%$ & 30 \\
\hline
\end{tabular}

\begin{tabular}{|c|c|c|c|c|c|c|c|c|c|c|c|}
\hline \multicolumn{6}{|c|}{ Тип населенного пункта, P=0,025, Хи-кв=5,0, ст.св.=1 } & \multicolumn{6}{|c|}{ Отделение до союза, $\mathrm{P}=0,000$, Хи-кв=14,1, ст.св. $=1$} \\
\hline \multicolumn{3}{|c|}{ Город } & \multicolumn{3}{|c|}{ Село } & \multicolumn{3}{|c|}{ До союза } & \multicolumn{3}{|c|}{ После или одновременно } \\
\hline Сожительство & $46,4 \%$ & 13 & Сожительство & $34,2 \%$ & 13 & Сожительство & $35,2 \%$ & 32 & Сожительство & $24,1 \%$ & 13 \\
\hline Брак & $53,6 \%$ & 15 & Брак & $65,8 \%$ & 25 & Брак & $64,8 \%$ & 59 & Брак & $75,9 \%$ & 41 \\
\hline Bcero & $1,5 \%$ & 28 & Bcero & $2,1 \%$ & 38 & Bcero & $5,0 \%$ & 91 & Bcero & $3,0 \%$ & 54 \\
\hline
\end{tabular}

\begin{tabular}{|l|l|l|}
\hline \multicolumn{3}{|c|}{1965 - 1974 } \\
\hline Сожительство & $55,7 \%$ & 128 \\
\hline Брак & $44,3 \%$ & 102 \\
\hline Всего & $12,6 \%$ & 230 \\
\hline
\end{tabular}

Опыт родителей, $\mathrm{P}=0,002$, Хи-кв=11,7, ст.св. $=1$ Не расходились 1 Расходились \begin{tabular}{|l|l|l|l|l|l|l|} 
Сожительство & $52,4 \%$ & 87 & Сожительство & $64,1 \%$ & 41 \\
\hline
\end{tabular} \begin{tabular}{|l|l|l|l|l|l|}
\hline Брак & $47,6 \%$ & 79 & Брак & $35,9 \%$ & 23 \\
\hline
\end{tabular} \begin{tabular}{|l|l|l|l|l|l|l|}
\hline Bcero & $9,1 \%$ & 166 & Bcero & $3,5 \%$ & 64 \\
\hline
\end{tabular} Предшествующее зачатие, $\mathrm{P}=0,023$, Хи-кв $=5,2$, ст.св. $=1$ \begin{tabular}{|l|l|}
\hline Зачатие не предшествует & Зачатие предшествует \\
\hline
\end{tabular} \begin{tabular}{|l|c|c|l|l|l|}
\hline Сожительство & $56,5 \%$ & 74 & Сожительство & $37,1 \%$ & 13 \\
\hline Брак & $43,5 \%$ & 57 & Брак & $62,9 \%$ & 22 \\
\hline Всего & $7,2 \%$ & 131 & Всего & $1,9 \%$ & 35 \\
\hline
\end{tabular}

Возраст на первой работе, $\mathrm{P}=0,028$, Хи-кв $=9,9$, ст.св. $=1$

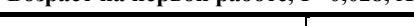

\begin{tabular}{|l|l|l|l|l|l|}
\hline \multicolumn{3}{|c|}{$<=\mathbf{2 0}$} & \multicolumn{3}{c|}{$>\mathbf{2 0}$} \\
\hline Сожительство & $63,8 \%$ & 44 & Сожительство & $48,4 \%$ & 30 \\
\hline Брак & $36,2 \%$ & 25 & Брак & $51,6 \%$ & 32 \\
\hline Вего & $3,8 \%$ & 69 & Вео & $3,4 \%$ & 62 \\
\hline
\end{tabular}

